Florida International University FIU Digital Commons

$4-1-2004$

\title{
Mobile architecture : offering new perceptions of the city
}

Valeria G. Bettoli

Florida International University

DOI: $10.25148 /$ etd.FI14051134

Follow this and additional works at: https://digitalcommons.fiu.edu/etd

Part of the Architecture Commons

\section{Recommended Citation}

Bettoli, Valeria G., "Mobile architecture : offering new perceptions of the city" (2004). FIU Electronic Theses and Dissertations. 1584. https://digitalcommons.fiu.edu/etd/1584

This work is brought to you for free and open access by the University Graduate School at FIU Digital Commons. It has been accepted for inclusion in FIU Electronic Theses and Dissertations by an authorized administrator of FIU Digital Commons. For more information, please contact dcc@fiu.edu. 
FLORIDA INTERNATIONAL UNIVERSITY

Miami, Florida

MOBILE ARCHITECTURE: OFFERING NEW PERCEPTIONS OF THE CITY

A thesis submitted in partial fulfillment

of the requirements for the degree of

MASTER OF ARCHITECTURE

by

Valeria G. Bettoli

2004 
To: Dean Juan Antonio Bueno

School of Architecture

This thesis, written by Valeria G. Bettoli, and entitled Mobile Architecture: Offering New Perceptions of the City, having been approved in respect to style and intellectual content, is referred to you for judgment.

We have read this thesis and recommend that it be approved.

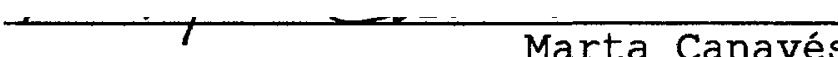

Marta Canavés

Alice Gray Read

Marilys Nepomechie, Major Professor

Date of Defense: Aril 1, 2004

The thesis of Valeria G. Bettoli is approved.

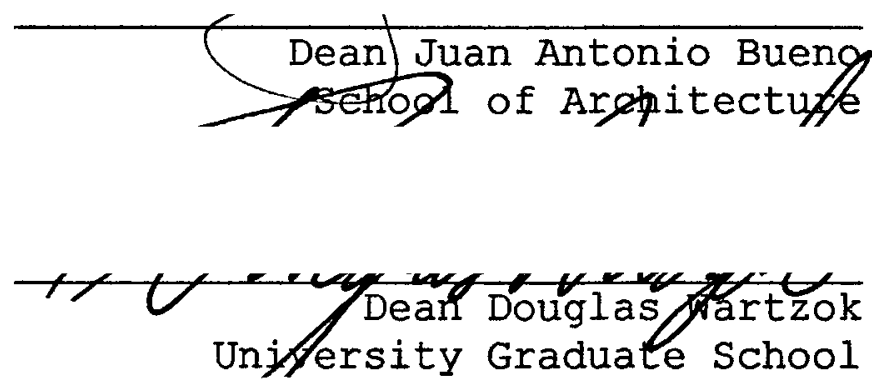

Florida International University, 2004 
DEDICATION

This thesis is dedicated to my parents who have supported me since the beginning of my studies.

Also, this thesis is dedicated to my husband who offered me his loving support and patience throughout this journey. 


\section{ACKNOWLEDGMENTS}

It is with utmost sincerity that I express my gratitude to all of those who have supported me throughout my degree commitments. First I would like to extend my appreciation to the members of my committee: Professor Marilys Nepomechie, Professor Marta Canavés and Dr. Alice Gray Read, not only for their guidance in writing this thesis, but also for their advice, concern, and encouragement during my studies. I would like to thank my Major Professor, Marilys Nepomechie who has inspired, guided, and encouraged me throughout my thesis. She gave me time, advice, support, and encouragement. Professor Marta Canavés, who offered ideas and suggestions that have been invaluable to this thesis. Dr. Alice Gray Read was a wonderful supervisor whose assistance and motivation were greatly appreciated. I would like to thank Professor Kevin Smith for his support and help with my renderings. To each of the above, I extend my deepest appreciation. 
MOBILE ARCHITECTURE: OFFERING NEW PERCEPTIONS OF THE CITY

Valeria G. Bettoli

Florida International University, 2004

Miami, Florida

Professor Marilys Nepomechie, Major Professor

The purpose of this thesis is to explore the design of mobile architecture that challenges traditional ideas of site through the design of a museum to commemorate immigration to the United States. This thesis develops a floating, moveable, inhabitable structure that moves on the inter-coastal waterways of South Florida, within the public areas of Miami. The floating museum offers new perceptions of the city and new means of occupying its various settings. Its architectural elements do not change but are read differently in each location. The museum brings its exhibitions to the city as an event. One moment it is there and the next it is gone.

In its design, the Museum of Immigration explores the experience of leaving one place to settle in another. As a prototype, it might be the first in a series of such buildings around the country that offers a new relationship between building and site. 
I. Mobile Architecture: Miami Museum of Immigration............

II. Mobile Architecture.............................

III. Edge Conditions "Land by the Gallon" $\ldots \ldots \ldots \ldots \ldots \ldots \ldots \ldots$

IV. A Community of Communities.....................

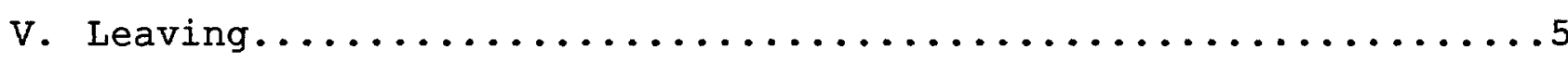

VI. The Voyage to America $\ldots \ldots \ldots \ldots \ldots \ldots \ldots \ldots \ldots \ldots \ldots$

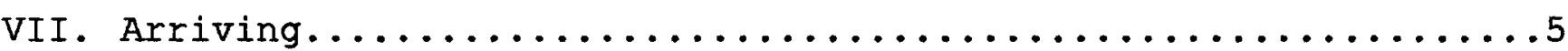

VIII. Architectural site analysis, preliminary drawings and models...8

IX. Architectural representations......................

X. Location of 3D Renderings......................... 18

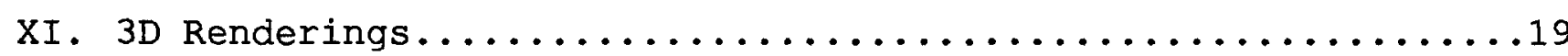

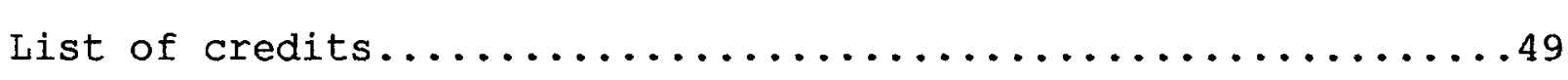

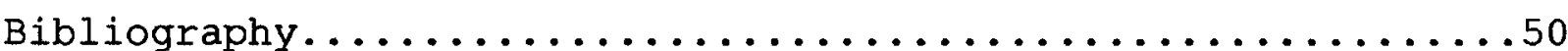


1- Guggenheim Museum Bilbao...

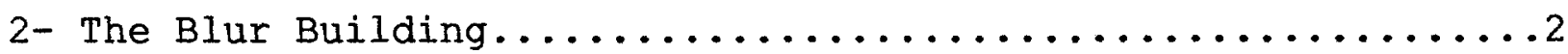

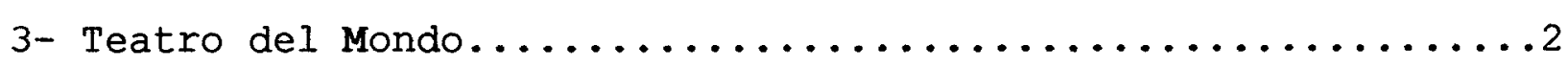

$4-$ Teatro del Mondo.................................

5- Floating Architecture.............................

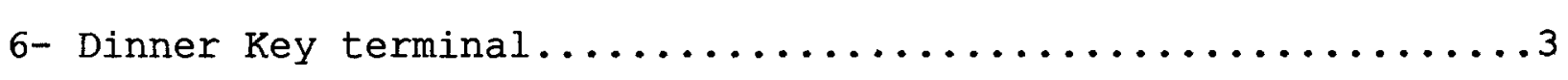

7- Intercostal of Biscayne Bay.....................

8- Traditional Vietnamese houseboats.................

9- Dinner Key terminal.........................

10- Water Pavilion, Floriade, Haarlemmermeer..............

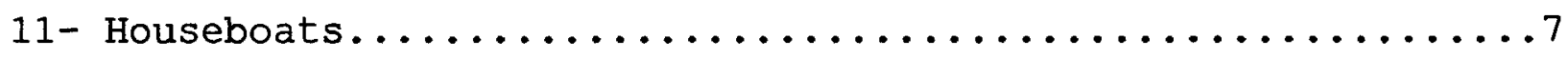

$12-$ Teatro del Mondo..........................

13- Stiltsville, Biscayne Bay $\ldots \ldots \ldots \ldots \ldots \ldots \ldots \ldots \ldots \ldots \ldots$

14- Floating Architecture/Inter-coastal of Biscayne Bay........7

$15-$ Houseboats. ............................

16- Floating architecture.......................

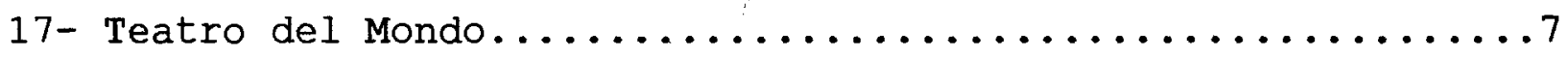

18- Iris-edged yatsuhashi (eight fold japanese bridge)........7

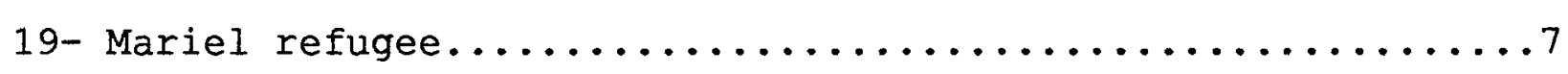

20- Cuban migrants arrive in Key West................. 
$21-$ Cuban refugee................................

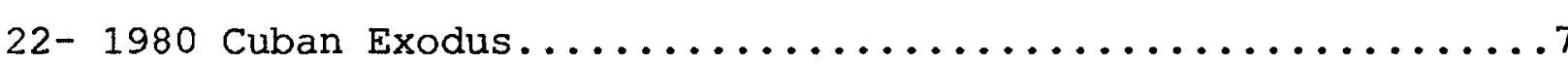

23- Docks. Background Ocean chart........................

24- Background picture (Haulover Beach Park Marina)/juxtaposed $3 d$ rendering...............................

25- Background picture (Pelican Harbor Marina)/juxtapose 3d rendering............................... 
I. Mobile Architecture:

Miami Museum of Immigration

My thesis is an argument for the potential of mobile architecture to challenge traditional ideas of site. This topic is explored through the design of a museum to commemorate immigration to the United States. The Museum of Immigration floats in Miami's Biscayne Bay and on the inter-coastal waterways of South Florida within the public areas of the city. This museum proposes to take an active role in the public life of the city, transforming a part of the inter-coastal waterways from a place of movement to a place of gathering that moves. The museum can be transported from area to area, city to city. It rises and falls with the inter-costal waterway's tides. It offers new perceptions of the city from the water and new means of occupying its edges. The elements that compose the museum can be rearranged for different exhibitions and different locations so they are read differently in each location. The floating museum brings its exhibitions to the city as an event.

The museum celebrates immigration, a central historical fact for this country and more specifically for this city. The museum will be dedicated to the cultural memory of all those who have arrived here from other countries. The Museum of Immigration will be a place for learning, research, and private study. It is a place where one can access information on migration and cross-cultural issues, information about family history, and a database of immigrants who arrived in this country from elsewhere. The museum also proposes to be a source for information on other museums and archives around the world. The holdings of the Museum of Immigration will change over time and the institution will increase the range of services it offers in order to make its presence felt among the residents and visitors to the city.

\section{Mobile Architecture}

$$
\text { Architects have long designed }
$$

buildings that appear to move, float or even look as if they were going to take off in flight.

Figure 1. Guggenheim Museum Bilbao, Frank Gehry.

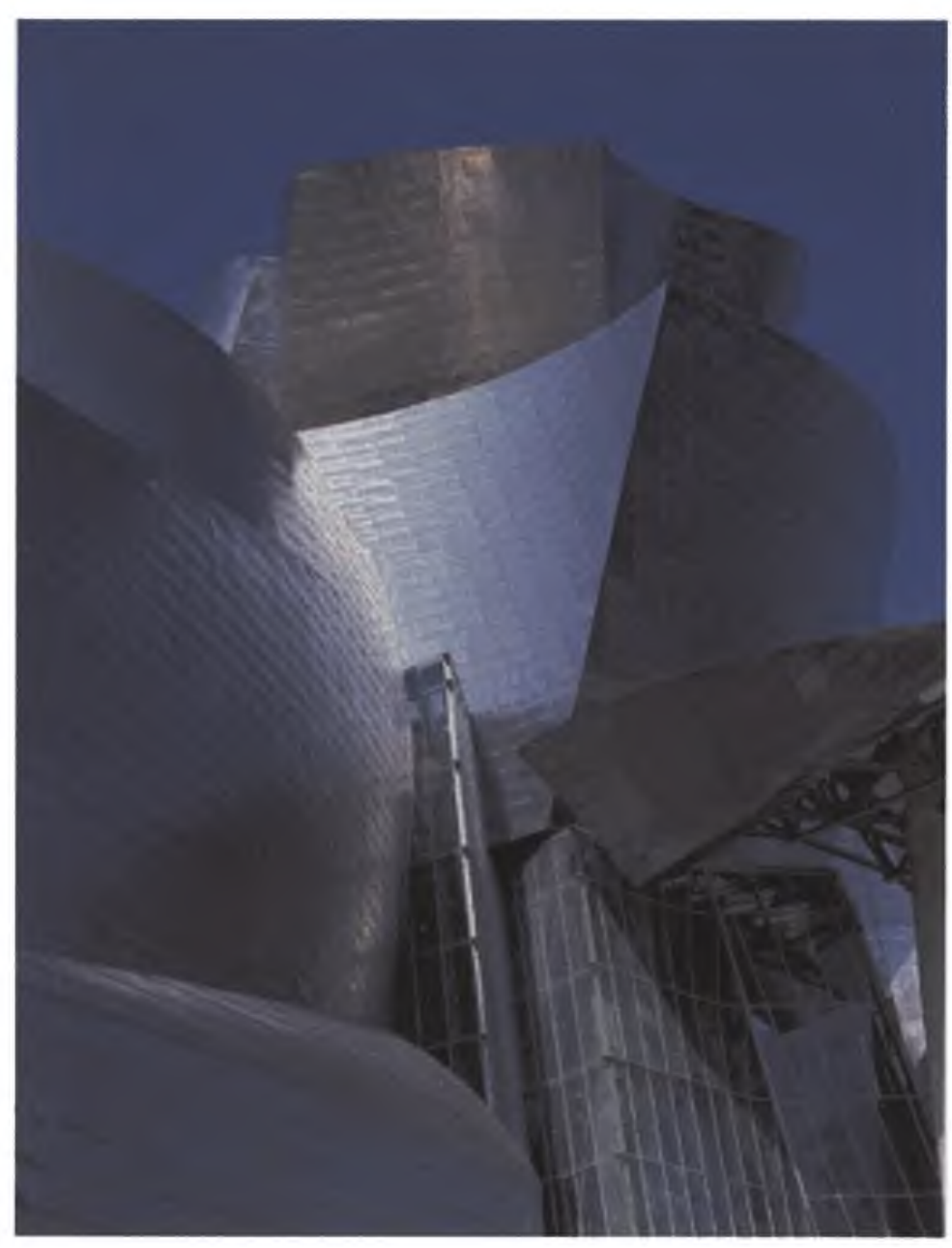


I. Mobile Architecture:

Miami Museum of Immigration

My thesis is an argument for the potential of mobile architecture to challenge traditional ideas of site. This topic is explored through the design of a museum to commemorate immigration to the United States. The Museum of Immigration floats in Miami's Biscayne Bay and on the inter-coastal waterways of South Florida within the public areas of the city. This museum proposes to take an active role in the public life of the city, transforming a part of the inter-coastal waterways from a place of movement to a place of gathering that moves. The museum can be transported from area to area, city to city. It rises and falls with the inter-costal waterway's tides. It offers new perceptions of the city from the water and new means of occupying its edges. The elements that compose the museum can be rearranged for different exhibitions and different locations so they are read differently in each location. The floating museum brings its exhibitions to the city as an event.

The museum celebrates immigration, a central historical fact for this country and more specifically for this city. The museum will be dedicated to the cultural memory of all those who have arrived here from other countries. The Museum of Immigration will be a place for learning, research, and private study. It is a place where one can access information on migration and cross-cultural issues, information about family history, and a database of immigrants who arrived in this country from elsewhere. The museum also proposes to be a source for information on other museums and archives around the world. The holdings of the Museum of Immigration will change over time and the institution will increase the range of services it offers in order to make its presence felt among the residents and visitors to the city.

II. Mobile Architecture

Architects have long designed buildings that appear to move, float or even look as if they were going to take off in flight.

Figure 1. Guggenheim Museum Bilbao, Frank Gehry.

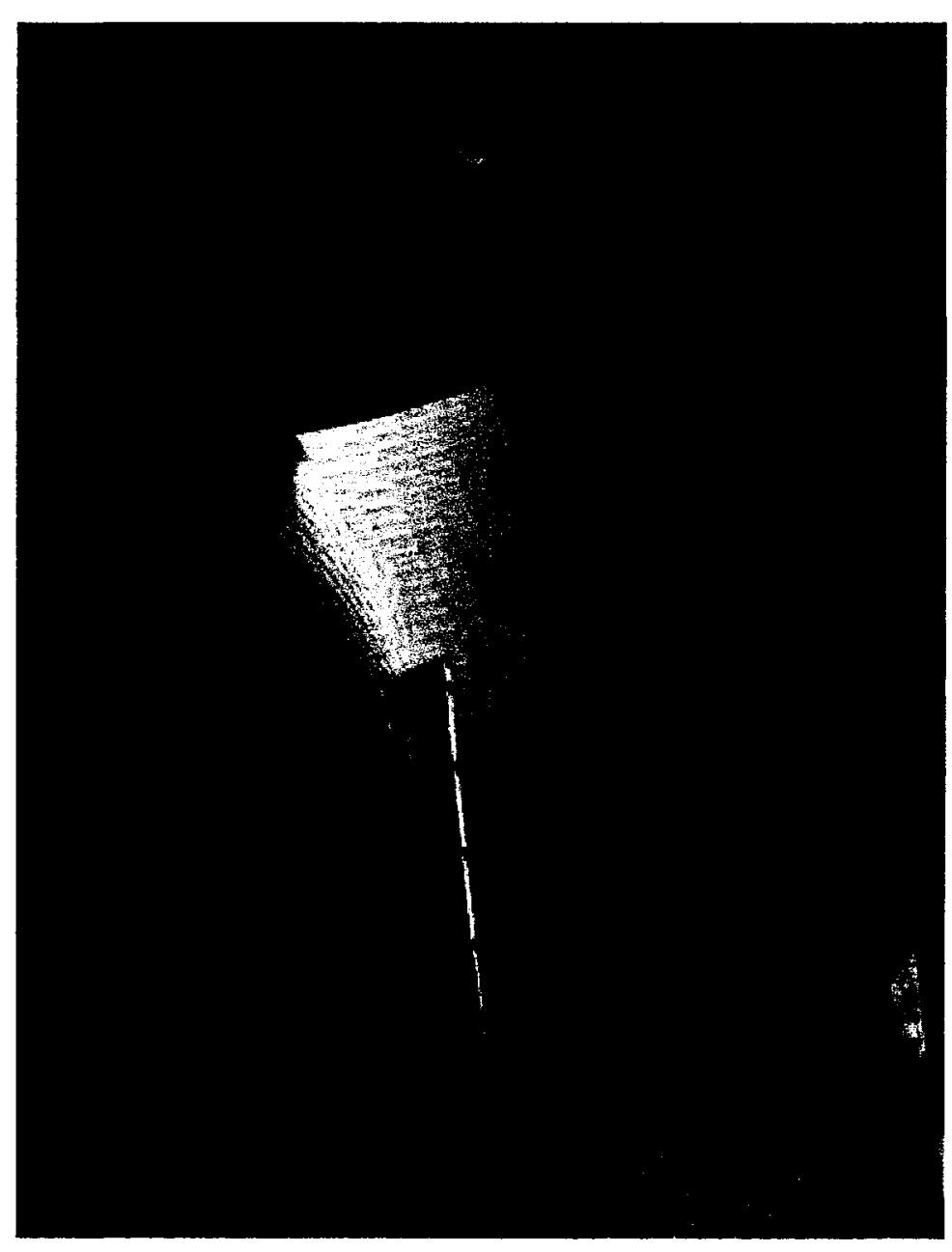


addressed this point in his design of the Teatro del Mondo (1979).

"... un elemento questo molto importante nella lectura di Venezia anche se poco notato nel suo lento muoversi..." (Teatro del Mondo) an important element in interpretation of venice even though its slow movement is not perceptible).

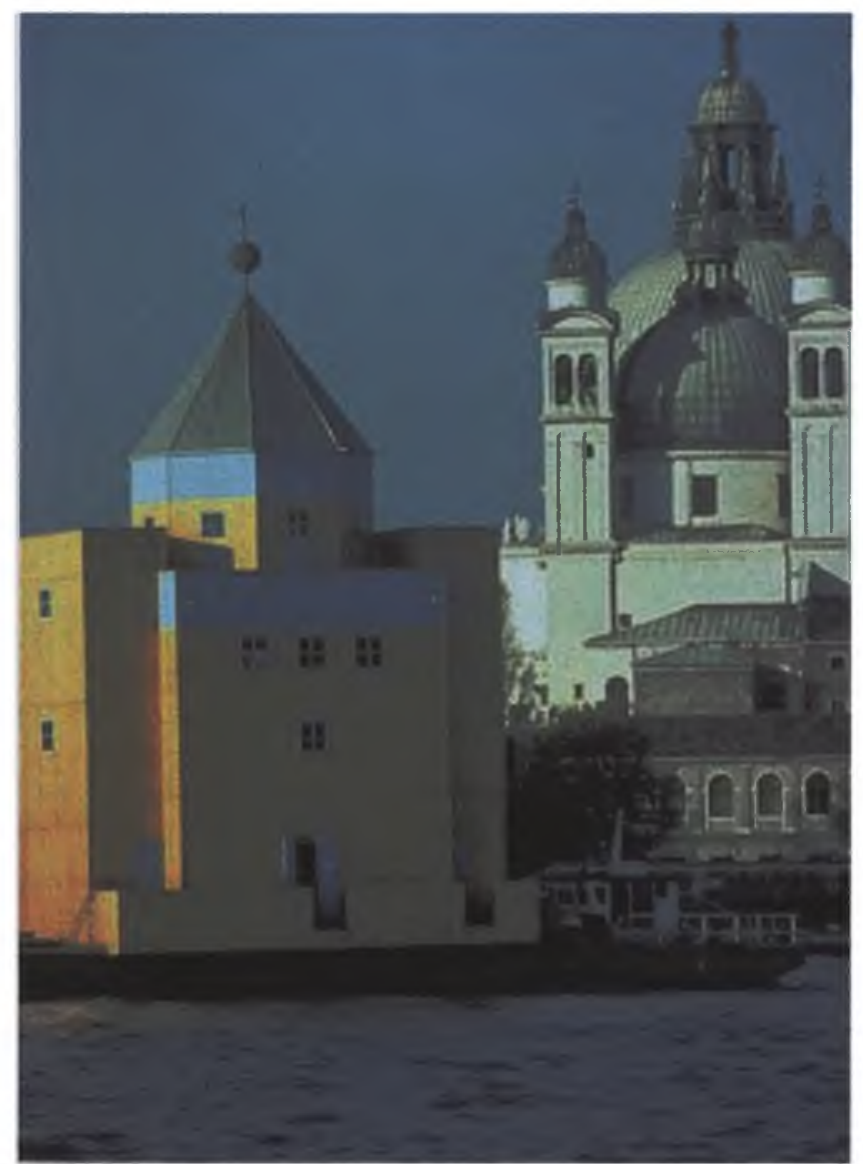

Figure 3. Teatro del Mondo, 1979.

Rossi, Aldo. Aldo Rossi, Architetture, 1959-1987. (Milano : Electa, 1987)

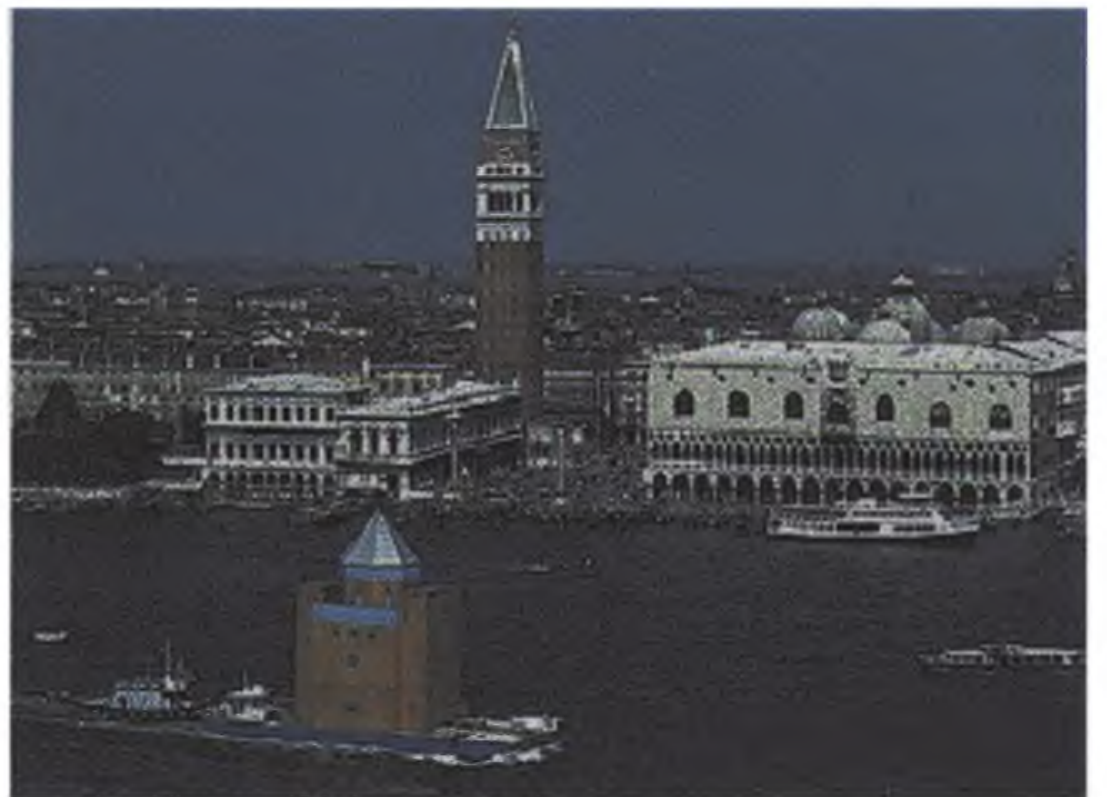

Figure 4. Teatro del Mondo, 1979.

Rossi's project articulated a belief that moving architecture might have an important effect the way people saw and interpreted their urban context. Despite, or perhaps because of its slow progress through the canals of Venice, his Teatro del Mondo made the city appear to move. Venice, built on pilings over a marsh, appeared to drift in relation to the floating Teatro. Through his reinterpretation of both the building program and the canals of Venice, Rossi's floating theater pavilion used the mobile metaphorically and literally. Aldo Rossi 
architecture to transform concepts of building, of program, and of place.

Mobile architecture can make a significant impression on how people perceive and experience the city. Sculptor Woodie Roehmer made an interesting proposal in her piece Floating Architecture, 1999. Roehmer introduced independent, fragile, floating elements that are loosely assembled to compose a sculpture. The pieces work together and independently in a variety of possible arrangements: they come together at times and at times operate separately. If one of the elements is detached, the remainder of the pieces can retain their compositional integrity, even as the detached piece functions by itself elsewhere. The elements that compose the Museum of Immigration can also work together and independently in a diversity of possible arrangements. The museum elements work metaphorically as individual immigrants that are part of a community.
Sometimes they work together, some times separately.

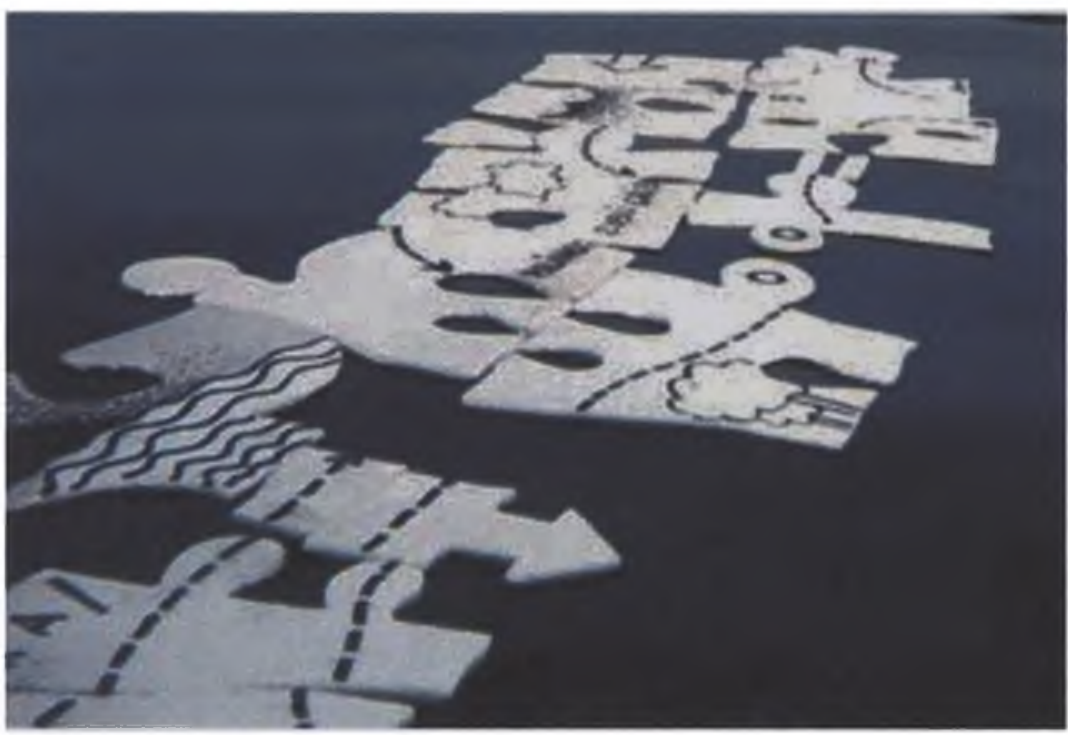

Figure 5. Floating Architecture, 1999.

Changing people's perspective on how they view architecture in the city will also bring about change in the city. Mobile buildings reach different people in different locations and in each community will be understood differently. Designing for such changeable circumstances is the challenge of this project.

III. Edge Conditions "Land by the Gallon"2 Miami lives in, through, and around water.

${ }^{2}$ George, Paul S. Ph.D. A journey through time: a pictorial history of South Dade (Virginia Beach, Va.: Donning Co., 1995)

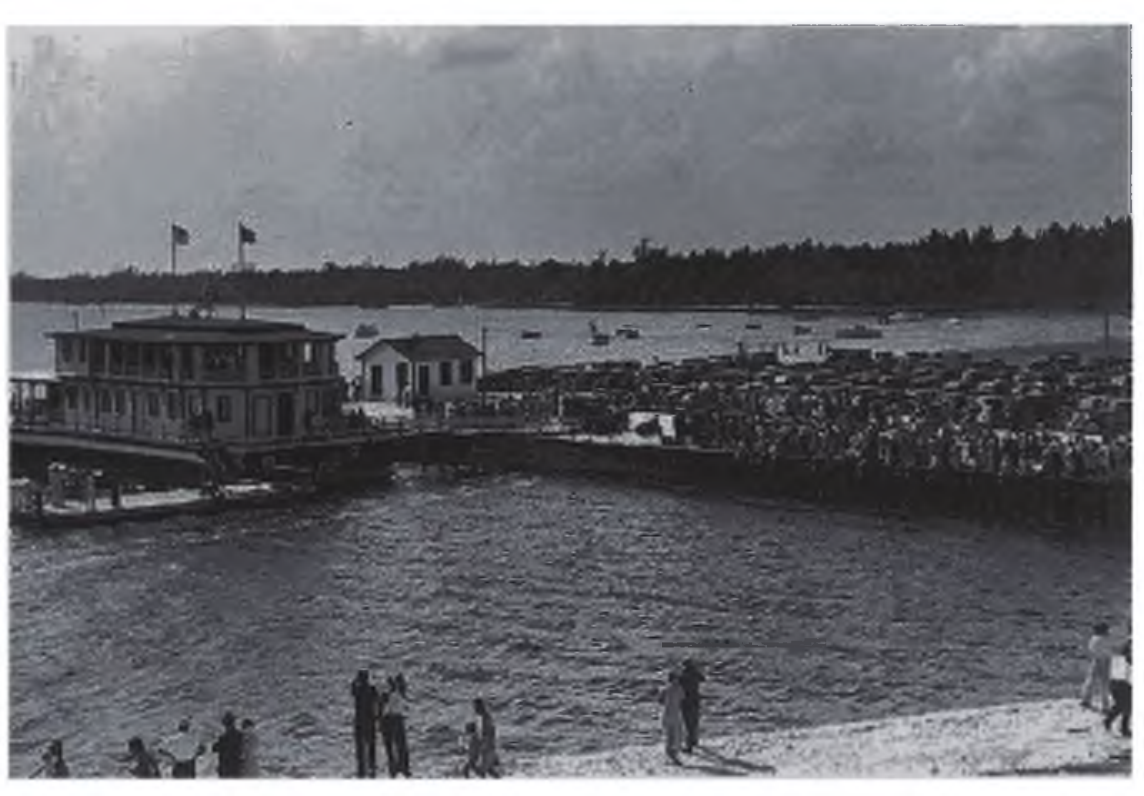

Figure 6. Dinner Key Terminal, Richter Library •

The Museum of Immigration will be in water, symbolizing the journey that many immigrants have made to reach Florida. In design, it will give visitors the precarious sense of freedom and independence that are part of the immigrant experience. The museum will be an assemblage of disparate components. As Miami is an assemblage of races, cultures, and nationalities, the museum is an assemblage of individual pavilions floating atop numerous structural barges. The use of 
barges is significant in that they comprise one of this country's earliest means of transporting goods and people. They represent the oldest American cargo vehicle still in use.

water necessarily plays an important role in the design: it is both primary condition and context. The architecture of the Museum of Immigration is simple, with clear-cut volumes and façades clad in reflective metal, untreated wood, and in assemblages of transparent and translucent glass. The museum pavilions are prisms that refract and reflect views of the city around them. In motion along the waterways of Miami, the museum barges are unique reminders of the legacy of immigration that they represent. Like the 'floats' in a parade, the pavilions represent the diversity of the city's population. Related to a tradition of religious pageantry, of testimonial and public engagement, the museum both draws from and defies the city's multiple heritage. It includes sixteen different types of pavilions, each with a specific purpose, as immigrants are different in their conditions, origins and beliefs. Four pavilions are dedicated to temporary exhibitions, four to permanent exhibitions, seven are home to media and research functions, and one houses a memorial space.

The pavilions are transported by tug boats and will dock at Haulover Beach Park Marina, Aventura Marina, Pelican Harbor Marina, Miami Beach Marina, and the Port of Miami. In one location for example, at the eastern extremity of the Florida International University Biscayne Bay Campus, the museum might be fully assembled in interconnecting barges to create an artificial island linked to dry land by two footbridges (See Longitudinal section pg. 13).

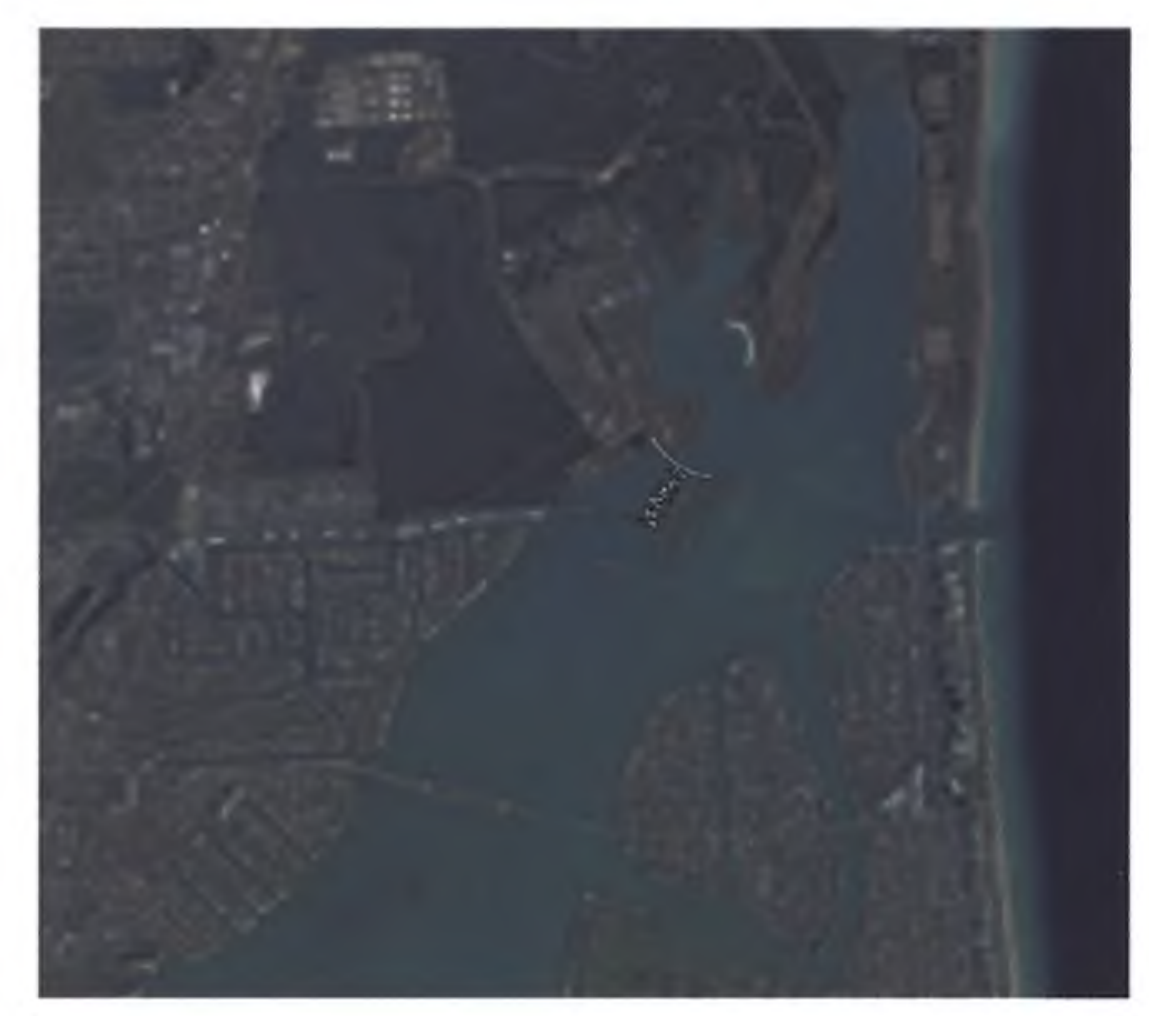

Figure 7. Inter-coastal Waterways in Biscayne Bay/with juxtaposed plan.

IV. A Community of Communities

Among people of Hispanic descent throughout the United States, the City of Miami holds enormous symbolic importance as both a metaphoric and a literal threshold between the United States, South America, and the Caribbean. For these, largely twentieth and now twenty-first century immigrants, Miami is as important as New York's Ellis Island was to European 
immigrants of the eighteenth and nineteenth centuries.

Many thousands of people from south America and the Caribbean have made Miami their permanent home, while retaining in their family memories dearly held accounts of crossing an ocean. Today, Miami is a fitting site for the establishment of a museum dedicated to the history of immigrants who have arrived from all over the world. In a floating museum, the experience and significance of immigration can be brought to life in an atmosphere in which the uncertainty of migration from one country and culture to another can be seen, heard and felt. Both the museum pavilions and the immigrants have distinct similarities.

Miami has been alternatively called a melting pot, a salad bowl, a gateway for merging and clashing cultures. Miami has been called the city of the future, yet everyone who settles here holds unbreakable ties to an often difficult past. Perhaps it is their connection to somewhere else that is unique to the City of Miami.

\section{Leaving}

The Museum of Immigration will explore the experience of leaving one place to settle in another, as well as the sacrifices that people are willing to make in order to attain a better future for their children. People have migrated to Miami for many reasons, some to escape war, hunger, religious persecution, or political repressions. Others have been lured by a sense of adventure, by the prospect of a new beginning, of owning land, of making a fortune, or of being reunited with loved ones.

VI. The Voyage to America

To visit this museum will be to spatially re-enact the ritual of arrival to this country, to literally experience walking on a bridge surrounded by water, and take steps to freedom just as millions have done before. Like a primitive dance, the visitor re-enacts the approach, and through a shared spatial experience understands an essential attribute of being an American.

All immigrants, no matter when they arrived in Miami, are linked by the common experience of a journey. Over the past century the journey of immigration to Miami has changed. Some immigrants have come by train, some by airplane, others have arrived after perilous sea voyages (legal and illegal) and lasting several days. The journey remains one of the most memorable aspects of any immigration experience. Recalling this history the museum is experienced as a journey trough the intercoastal waterways of Miami.

VII. Arriving

Immigrants are still arriving in this country but the numbers are fewer. Governmental regulations are much tighter and admissions more difficult than ever. 
Getting to Miami is one thing, but staying in this country is quite another. Settling into a new country is not easy. Immigrants have had to adapt to an unfamiliar environment and lifestyle while maintaining aspects of their previous culture and way of life.

The museum will explore some of the reasons why they came, where they settled and how they started a new life in Miami. The galleries are intended to function as an immigration timeline that highlights key events in the history of immigration in this city. Finally, a memorial space will be developed to play tribute to those who have died in search of a better tomorrow. The museum will be a floating, movable inhabitable space. As a prototype, it might be the first in a series of such buildings around the country, changing the definition of the relationship between building and site. 
MUSEUM

LEAVING

ELOATING

INDEPENDENCE

IMMIGRATION
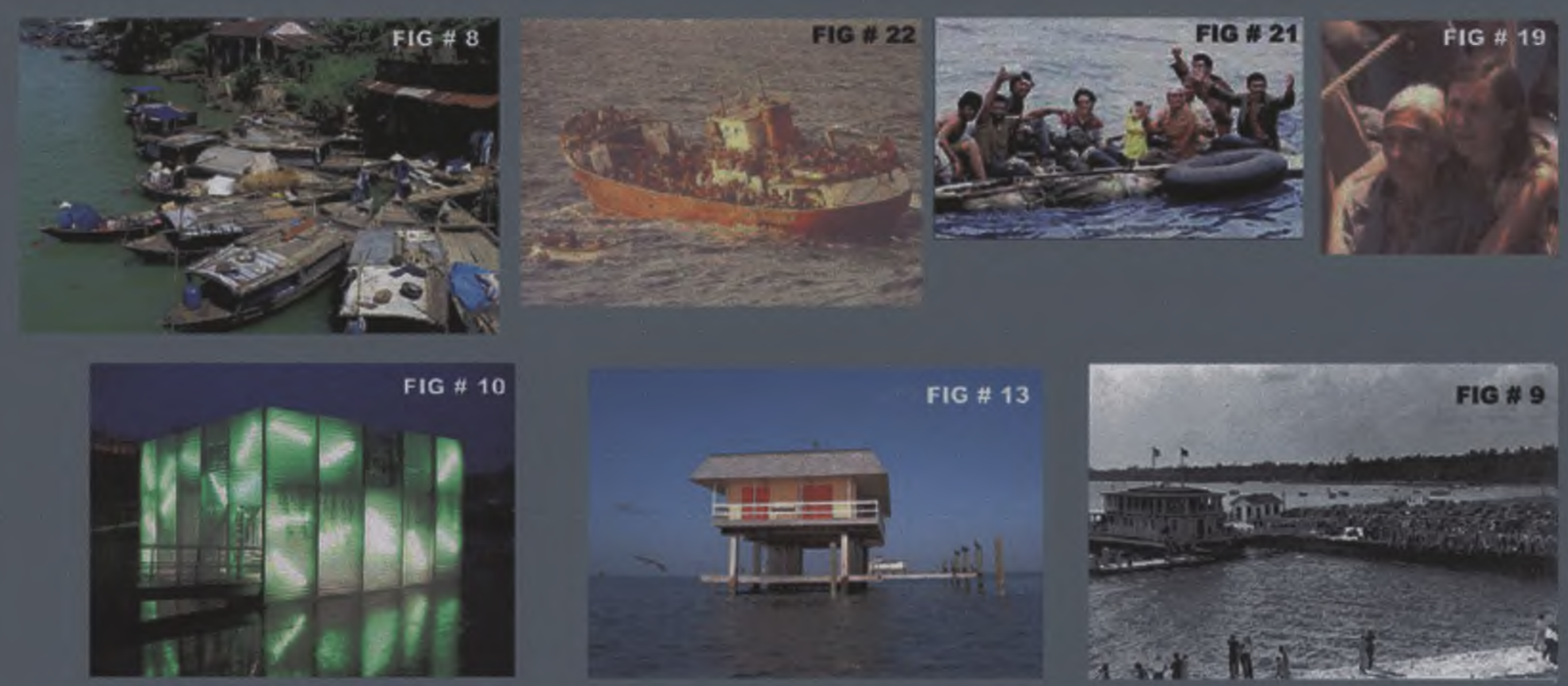

FREEDOM

JOURNEY

MOVING
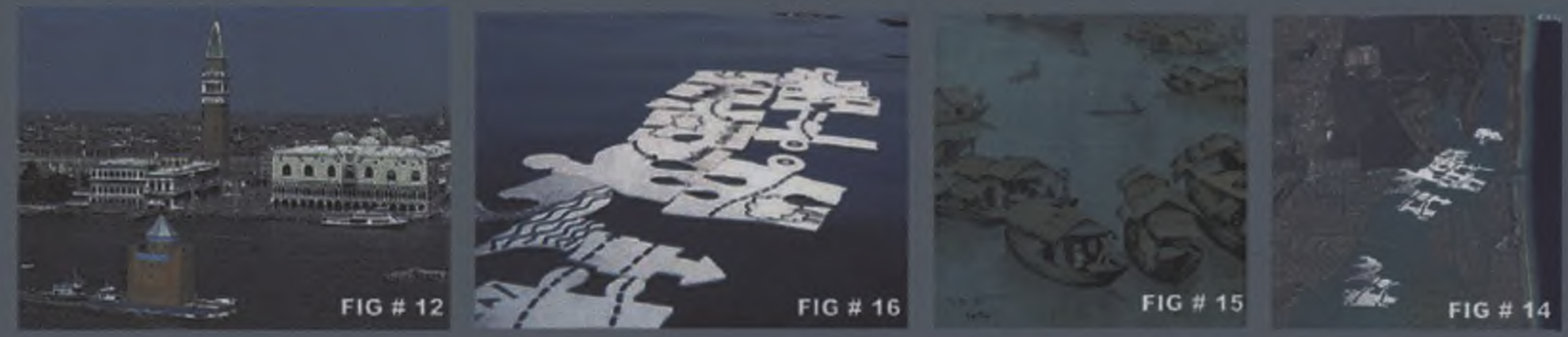

WATER

CITY
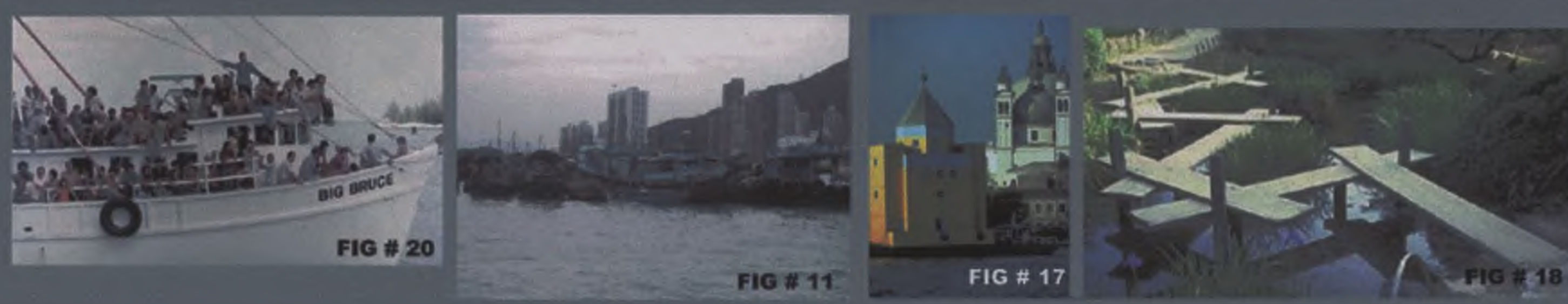
ARCHITECTURAL SITE ANALISYS, PRELIMINARY DRAWINGS AND MODELS 

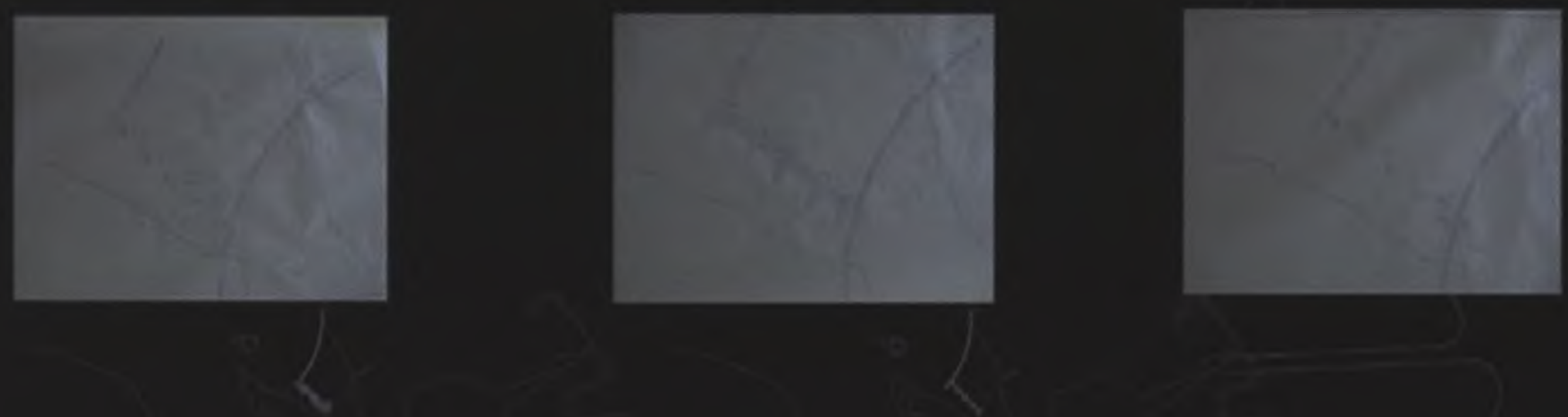

PROCESS
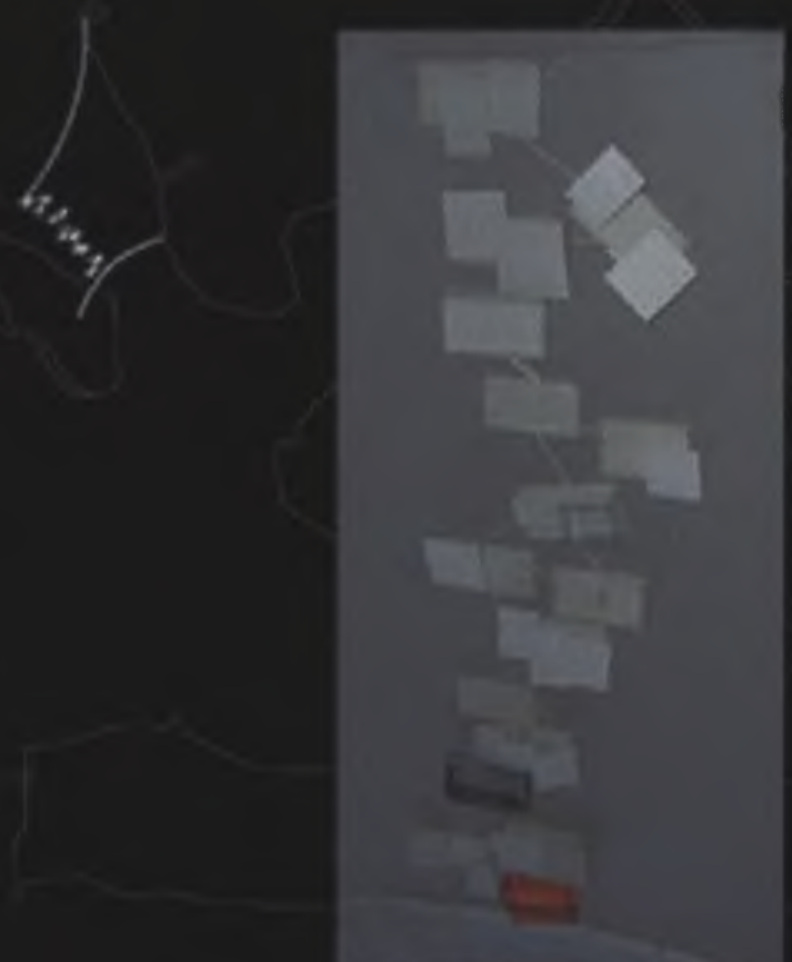

Lan
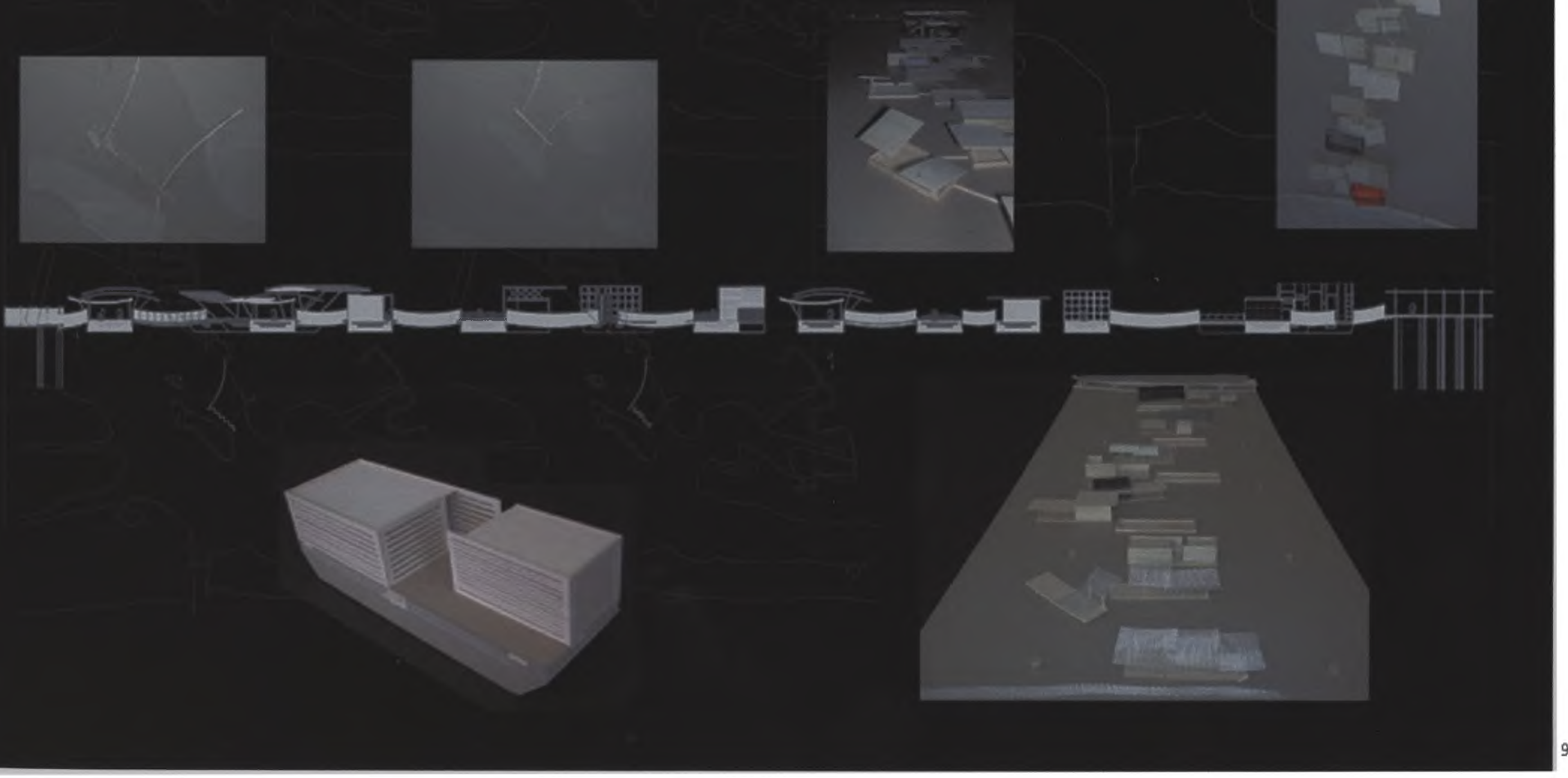
ARCHITECTURAL REPRESENTATIONS 


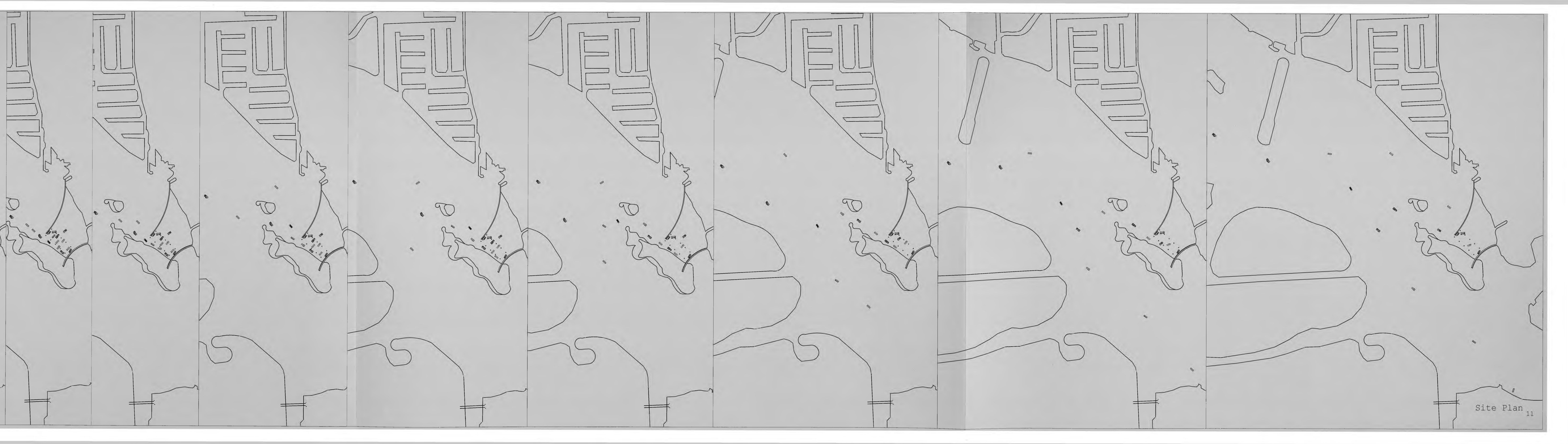




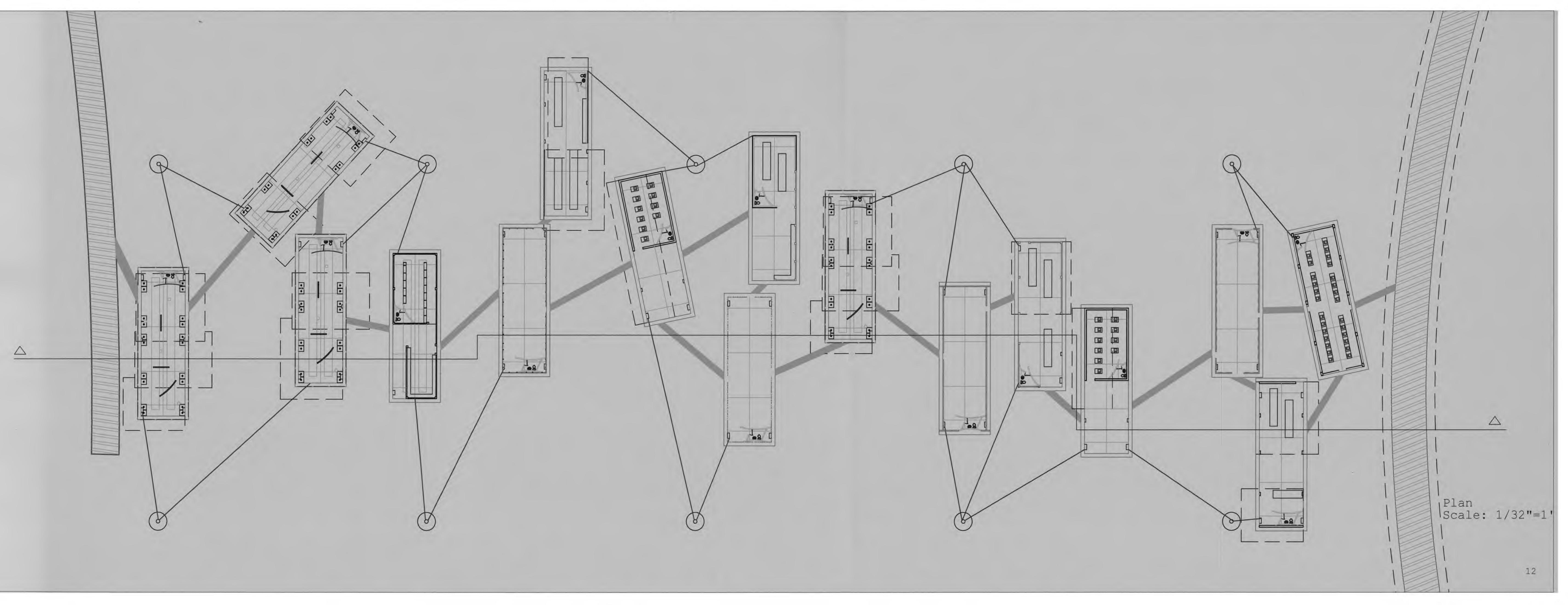




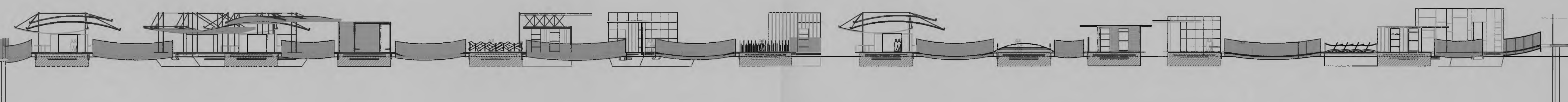





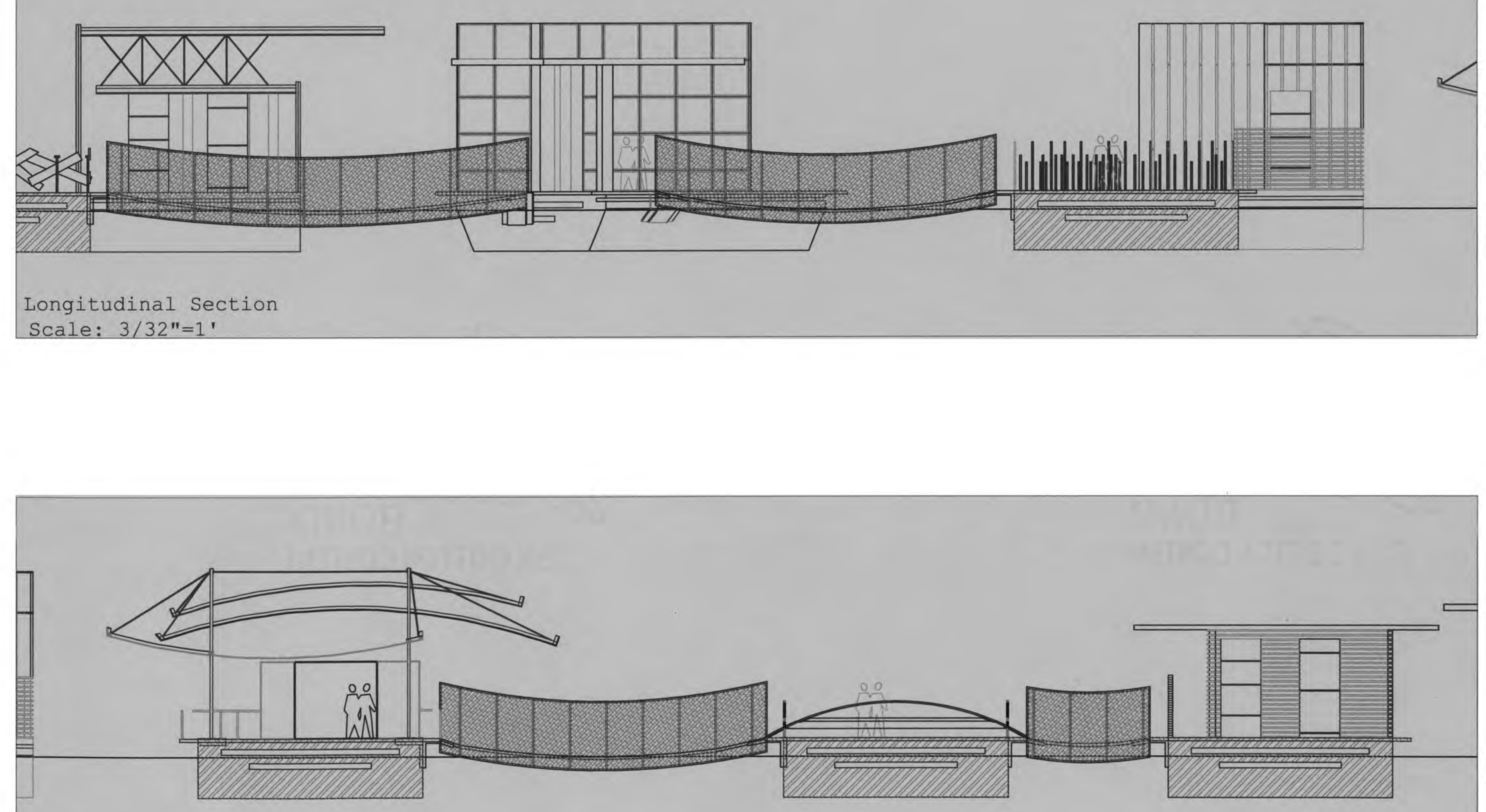

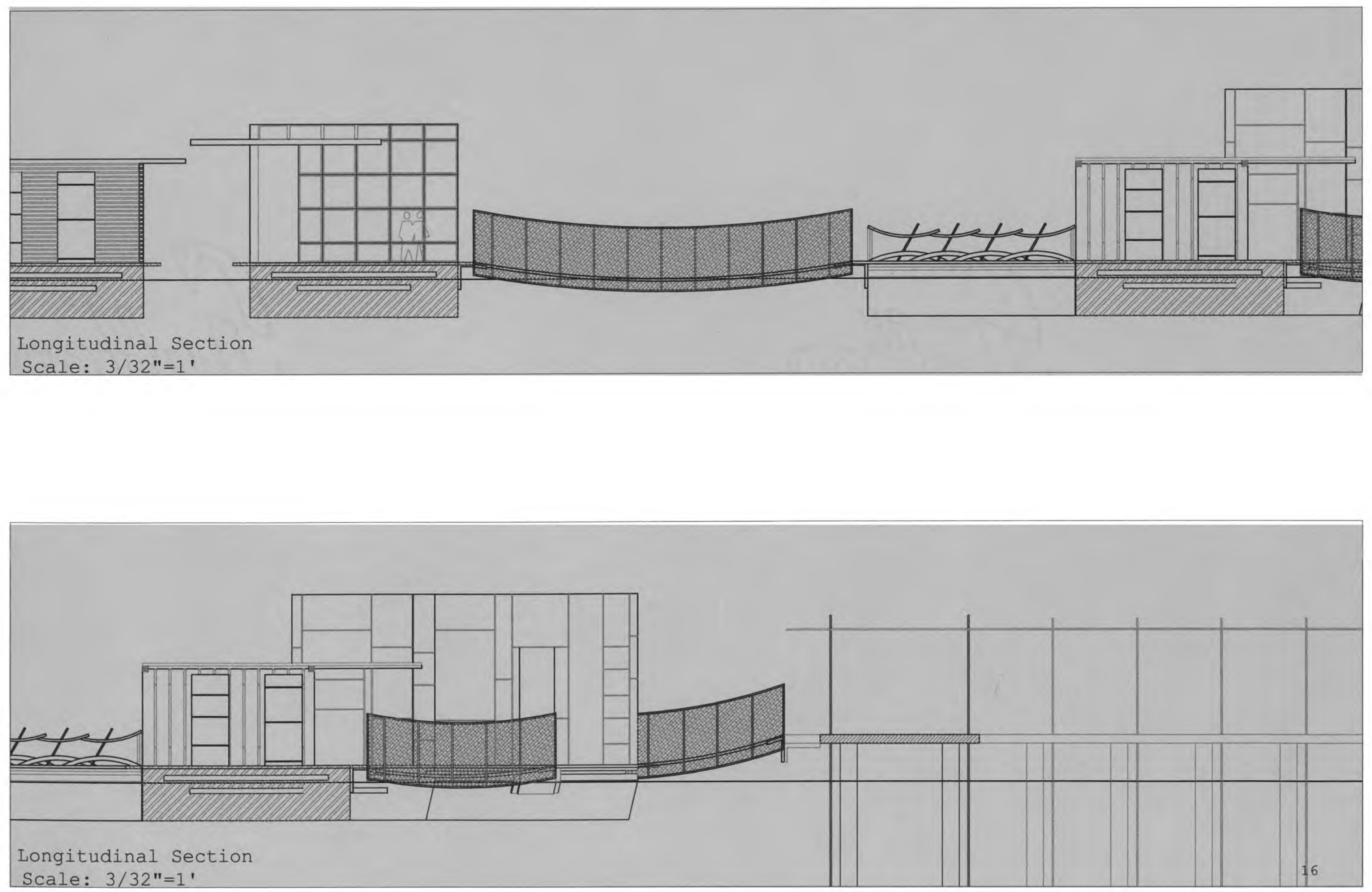


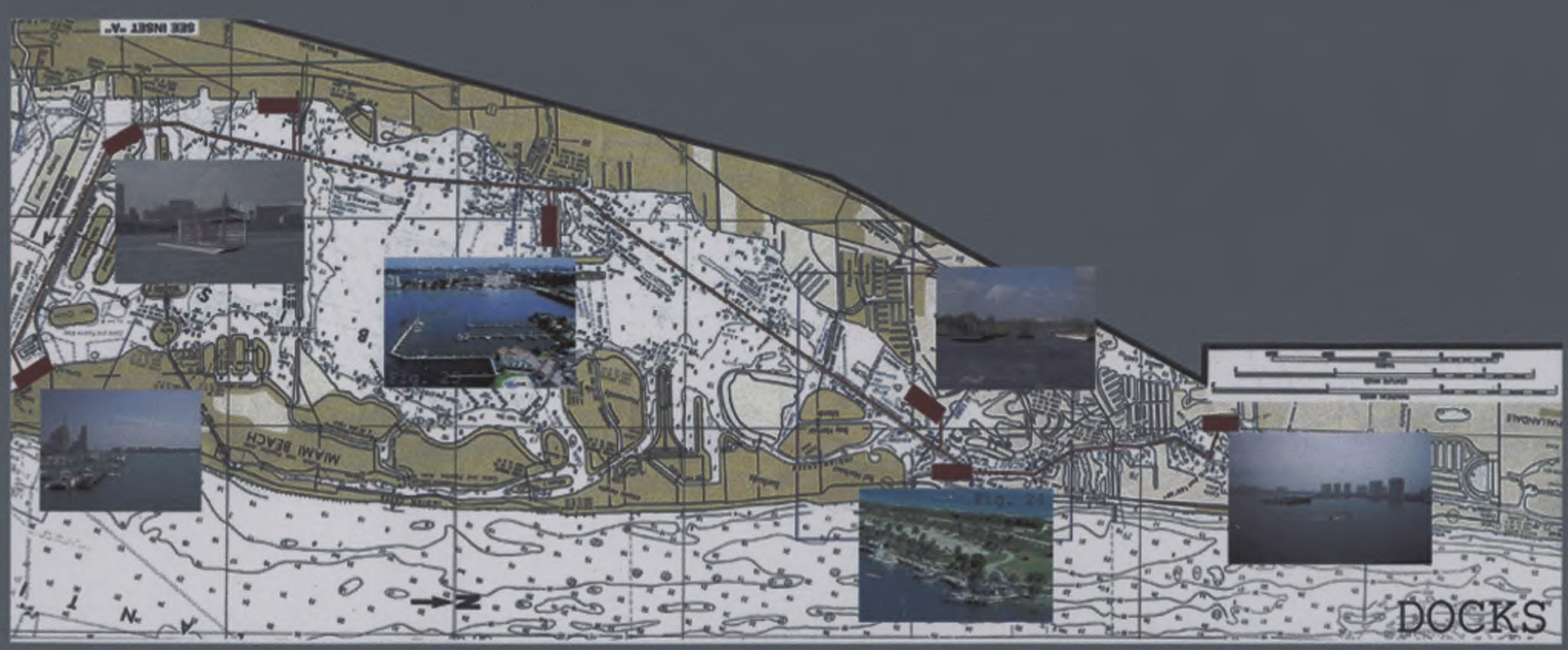

Figure 23. Pierises of the esctinas with thexaposed 


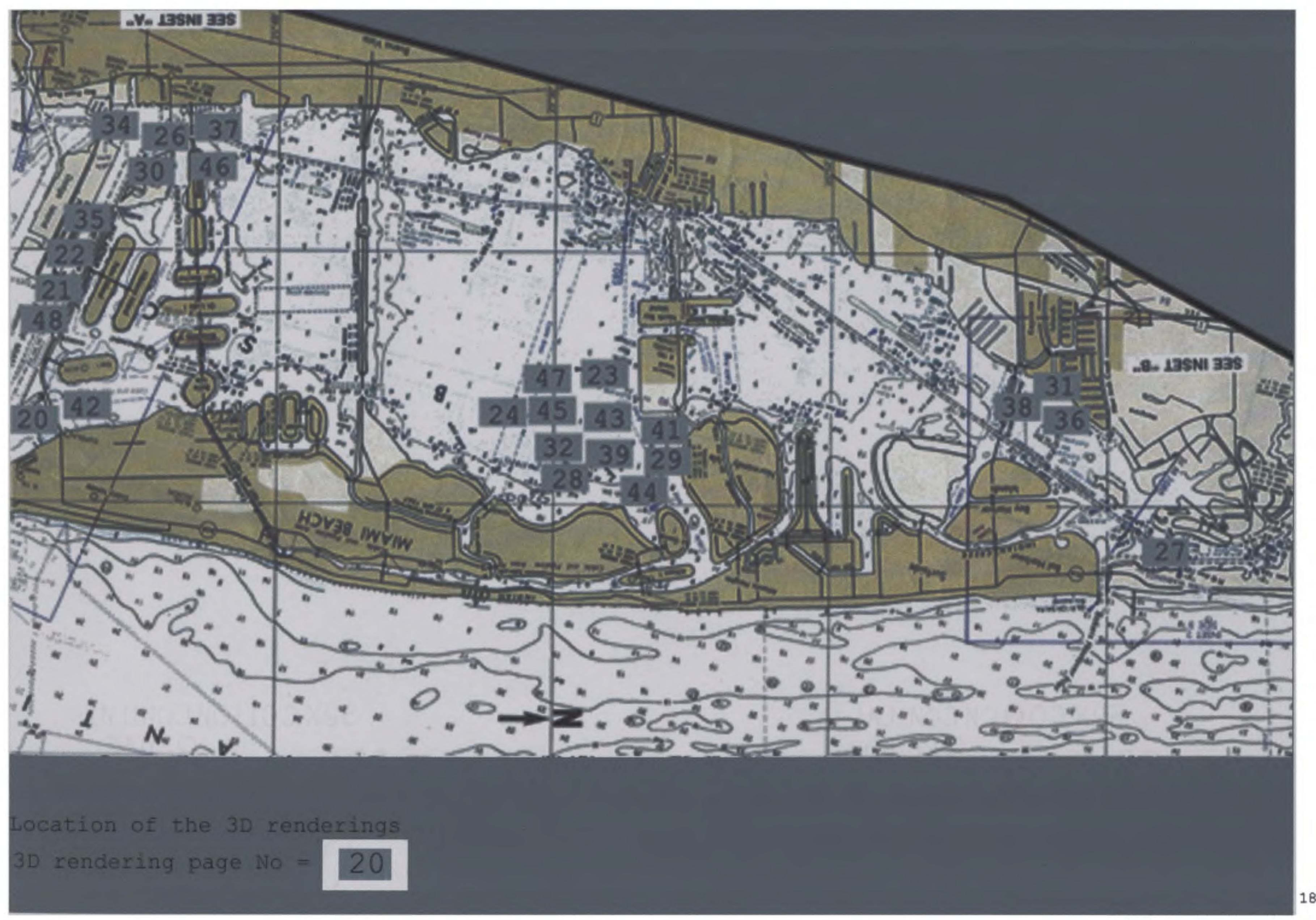


THE MUSEUM BEING PART OF THE CITY 


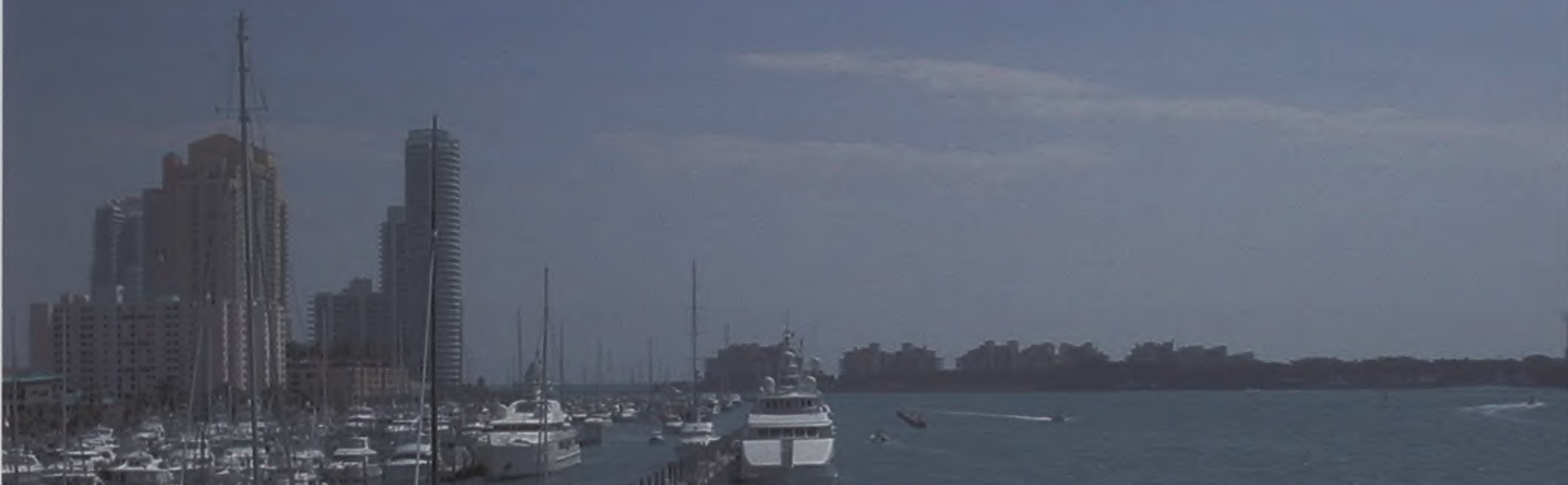

2.

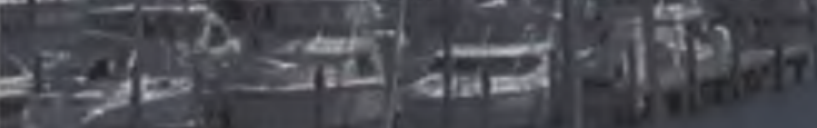

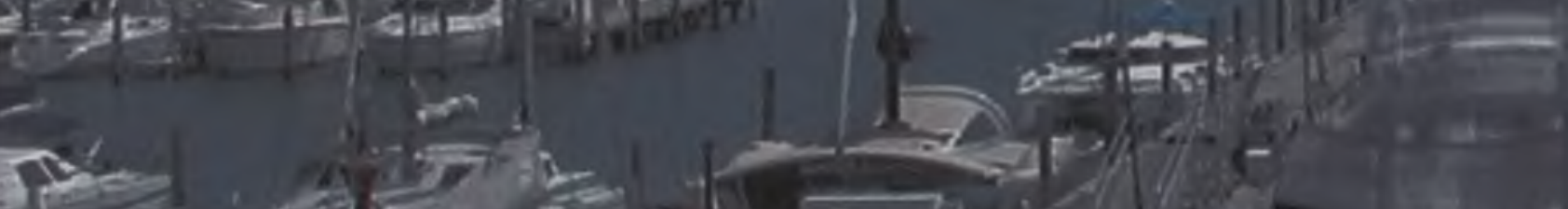

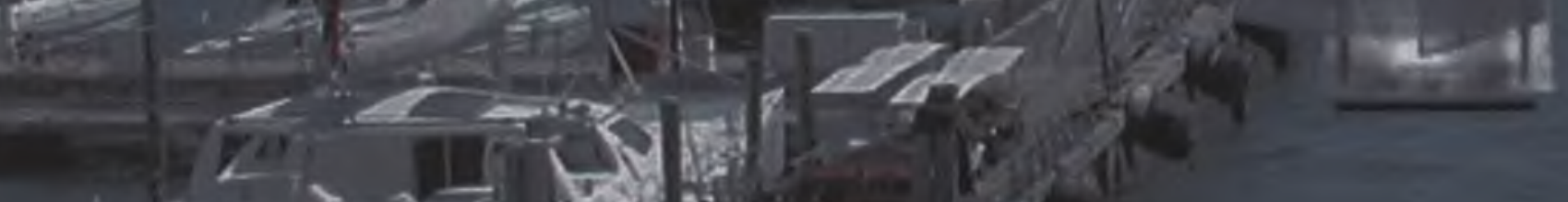

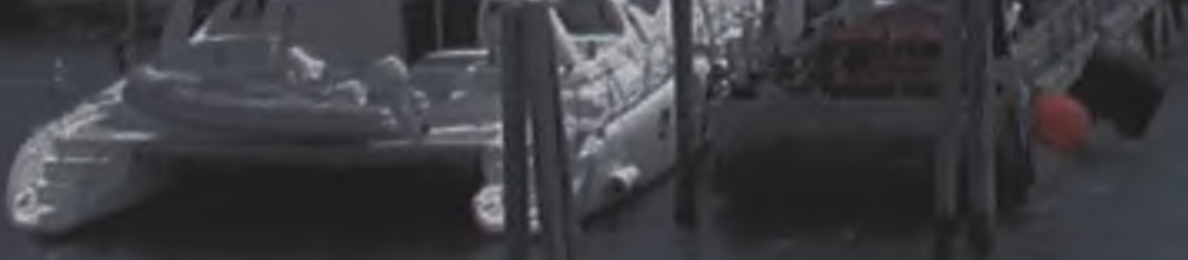




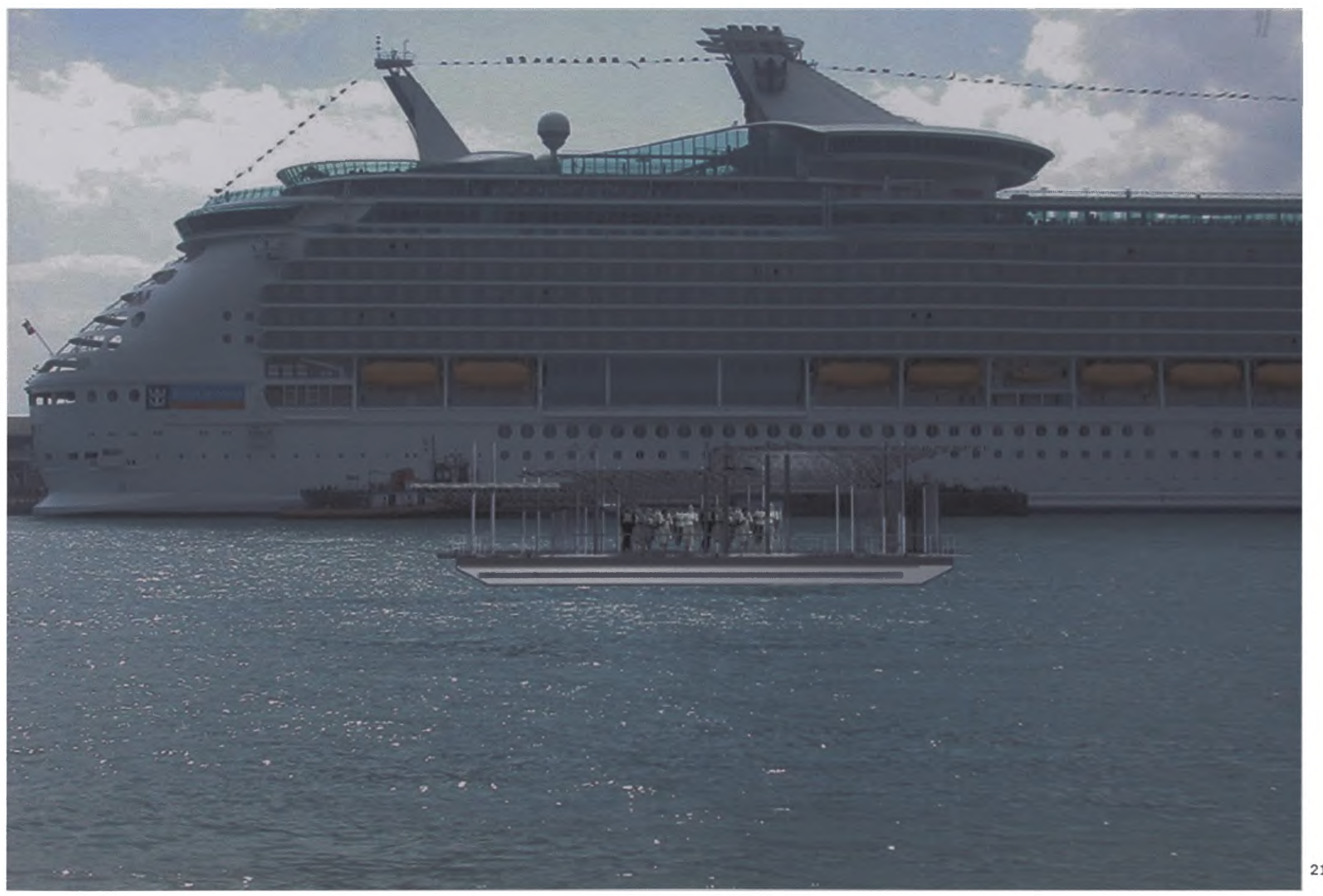




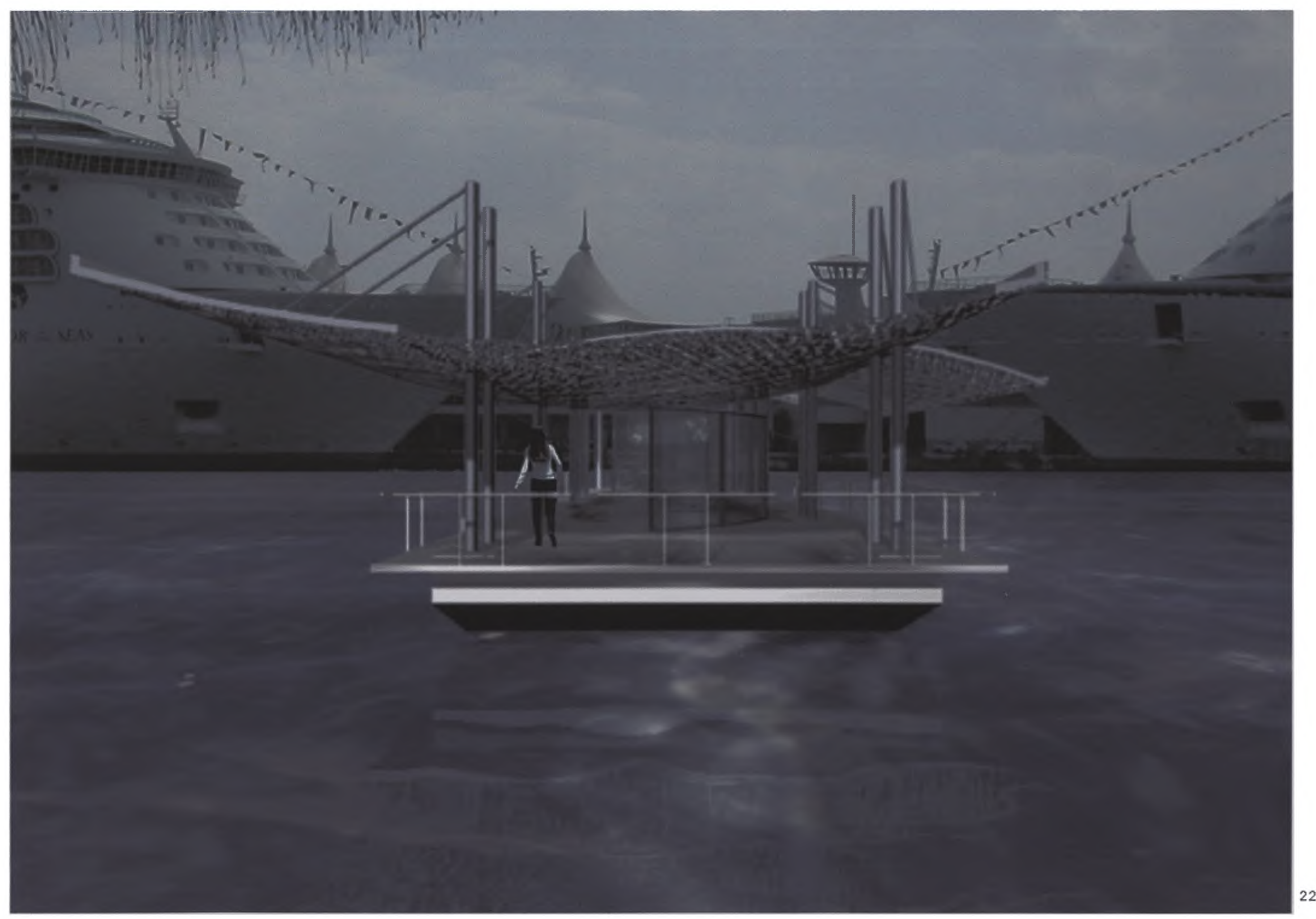




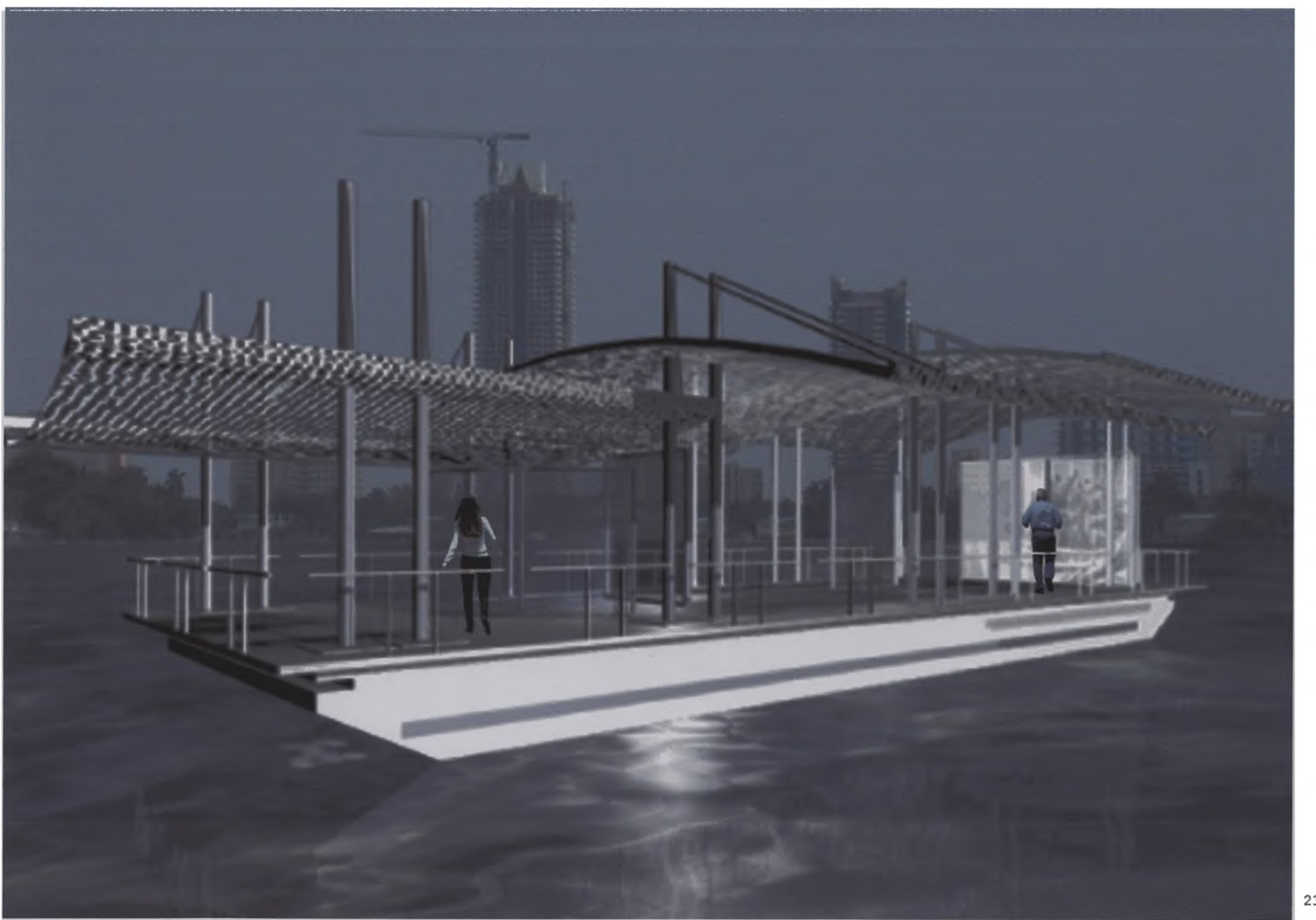



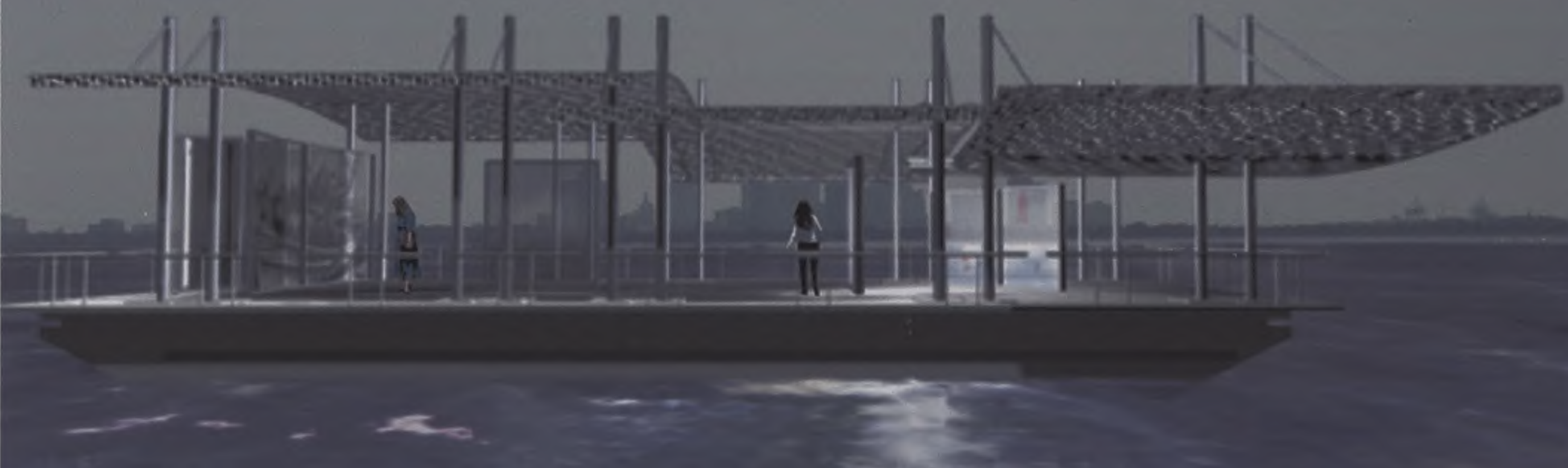


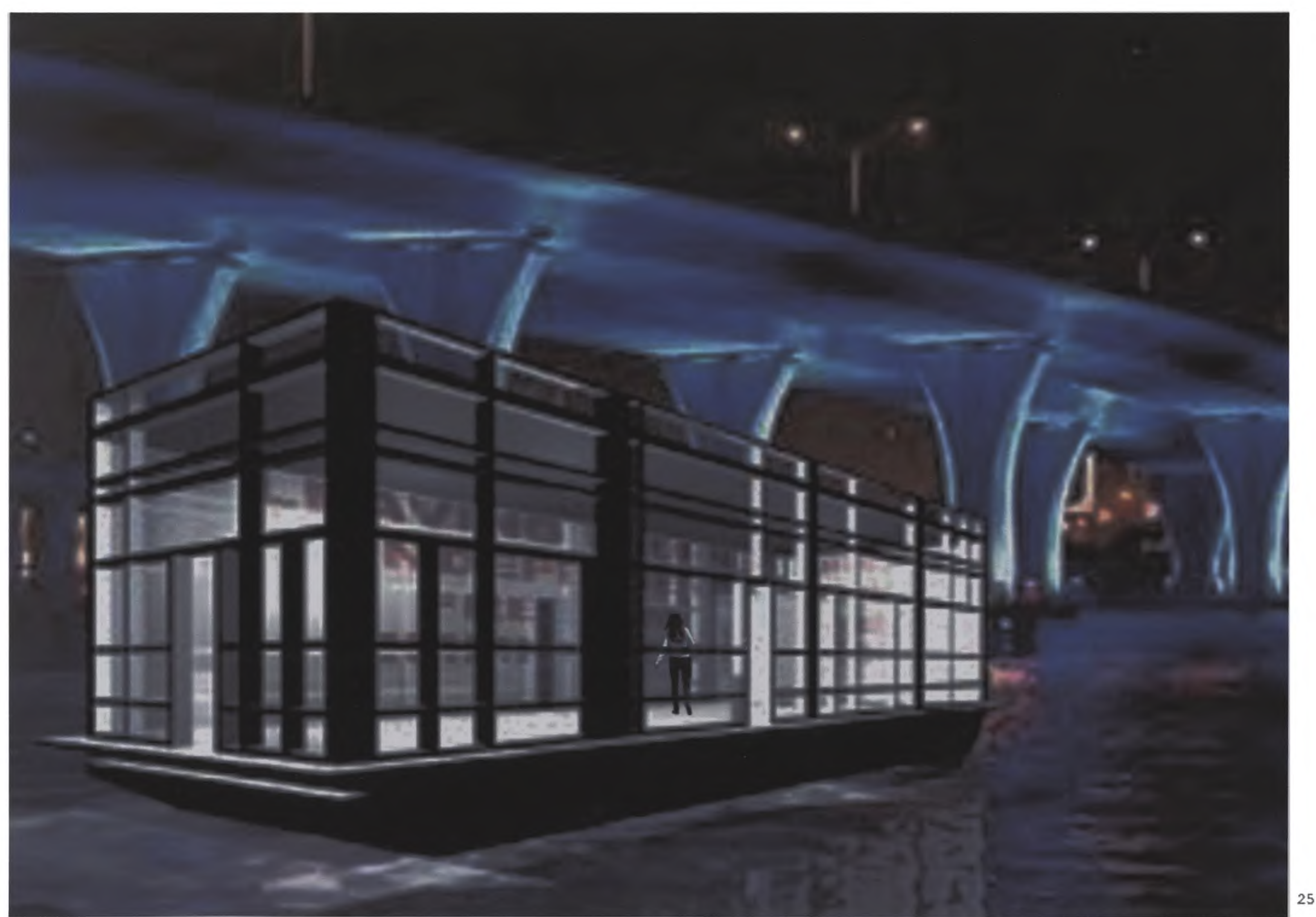




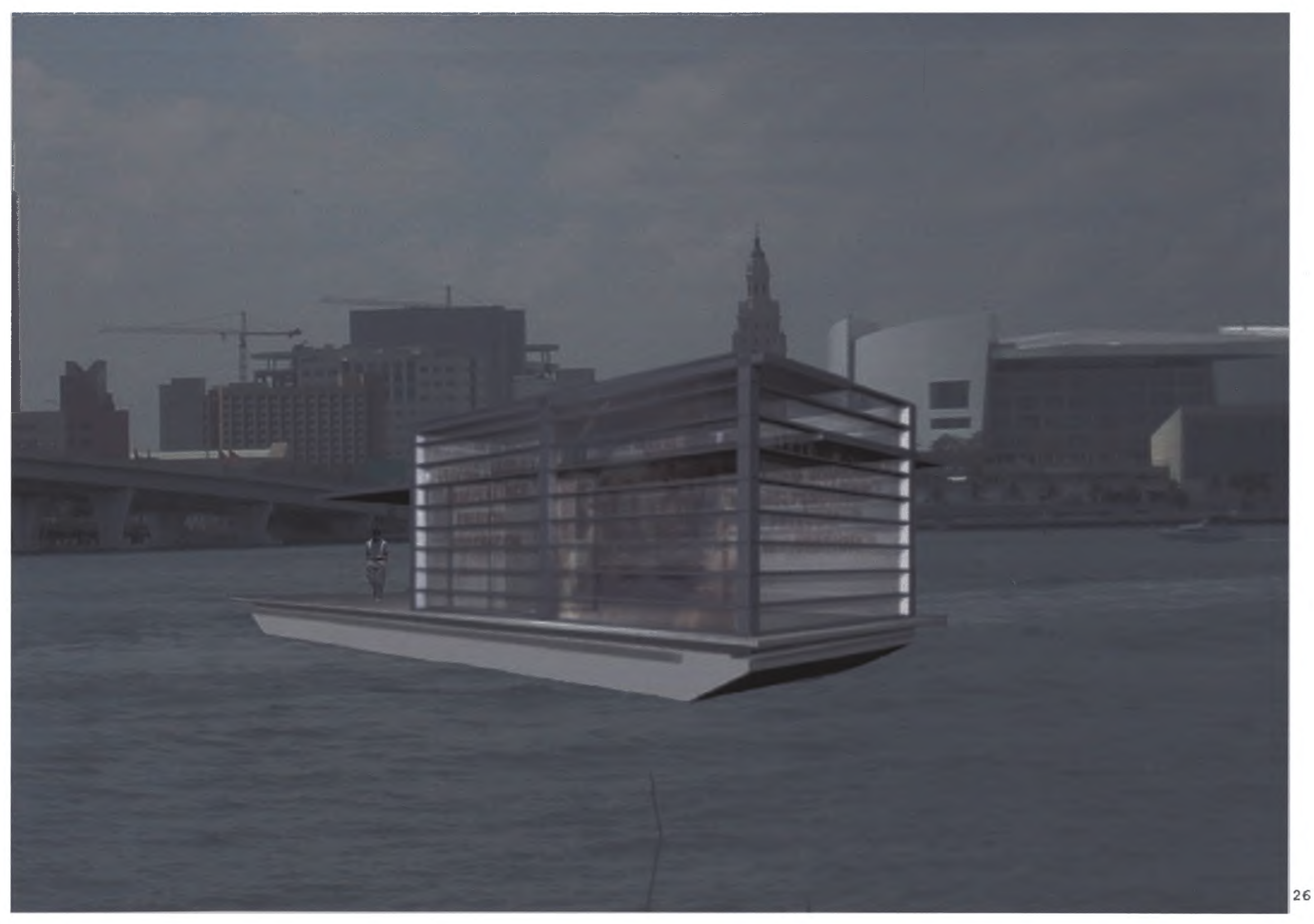




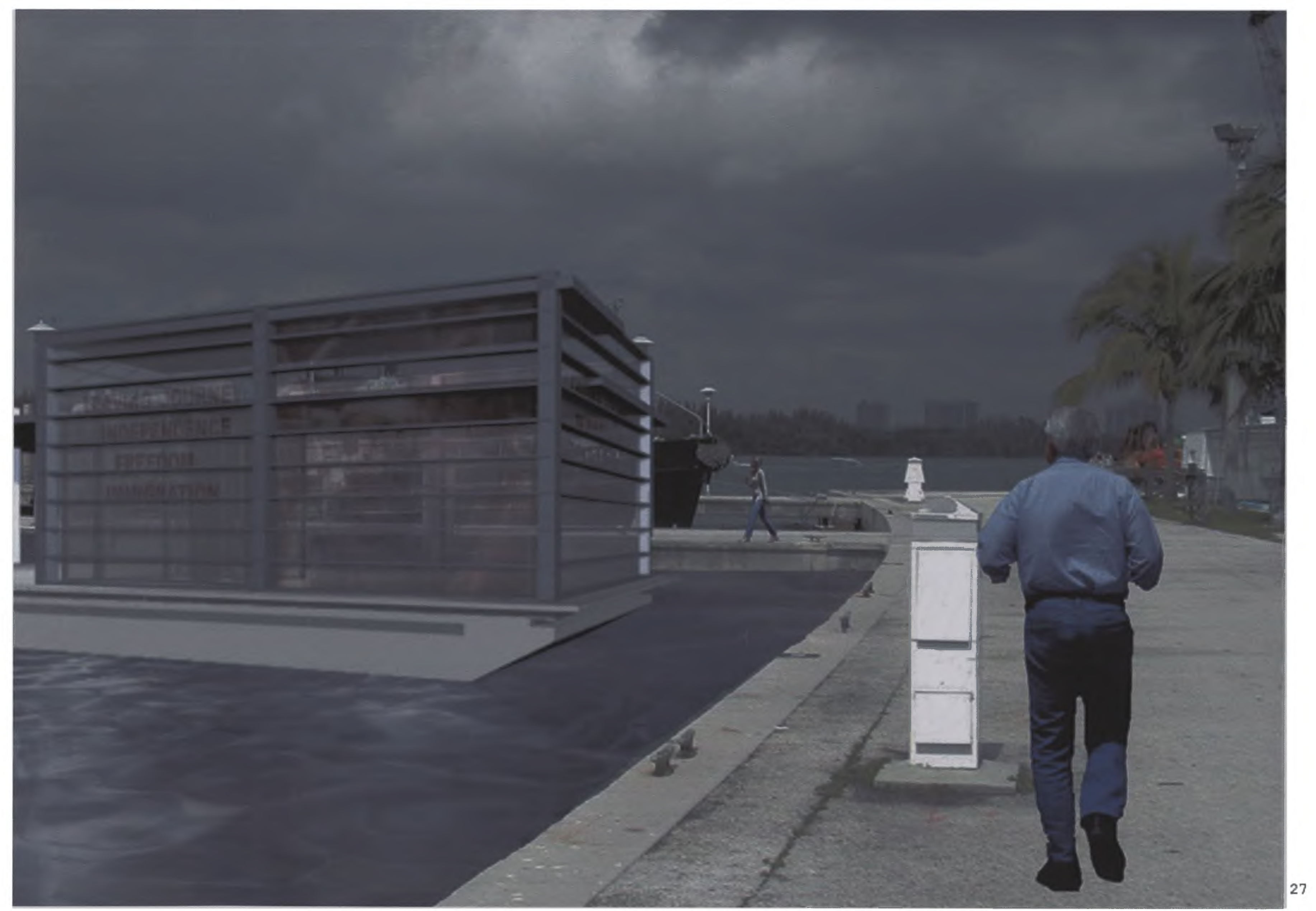




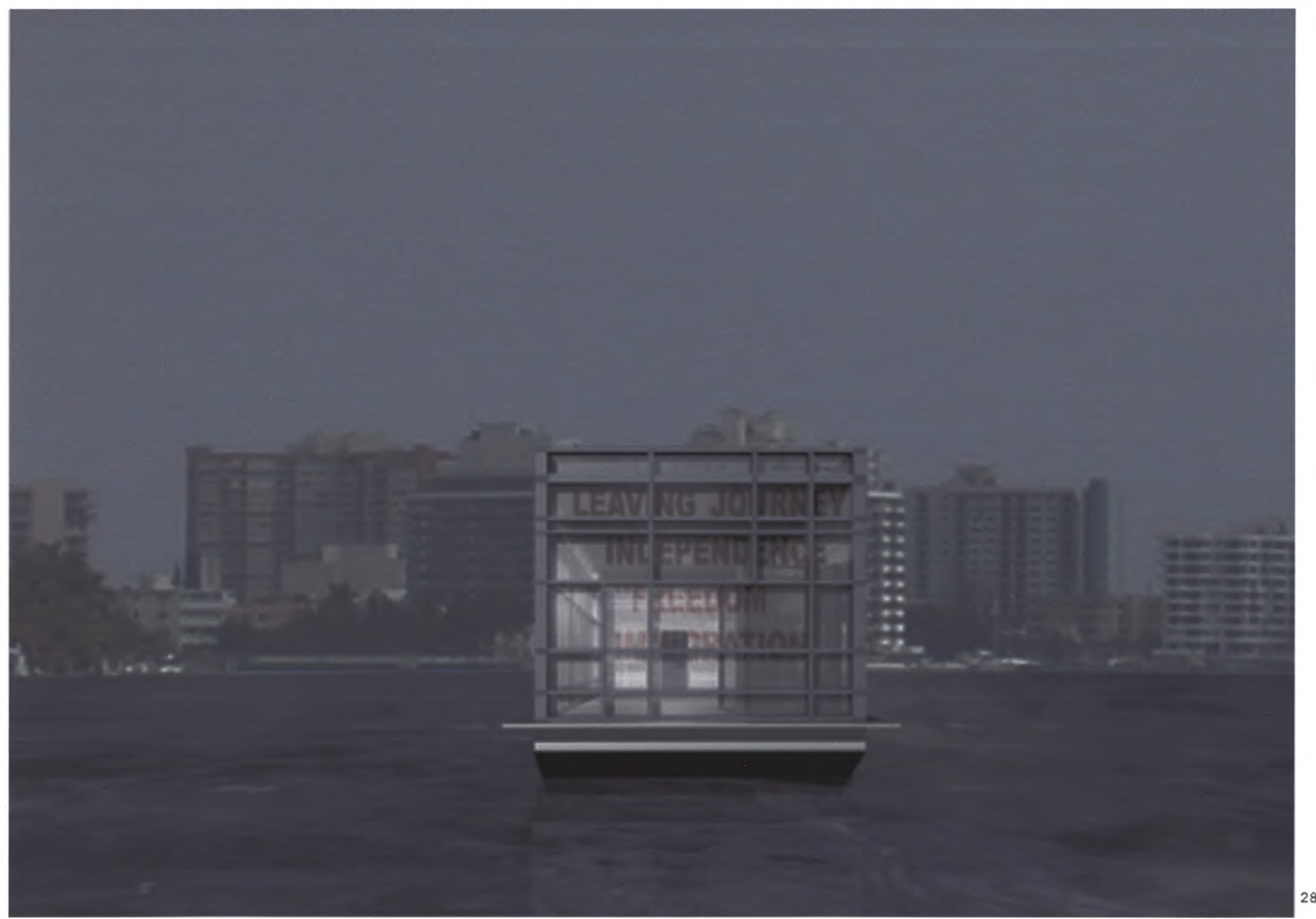




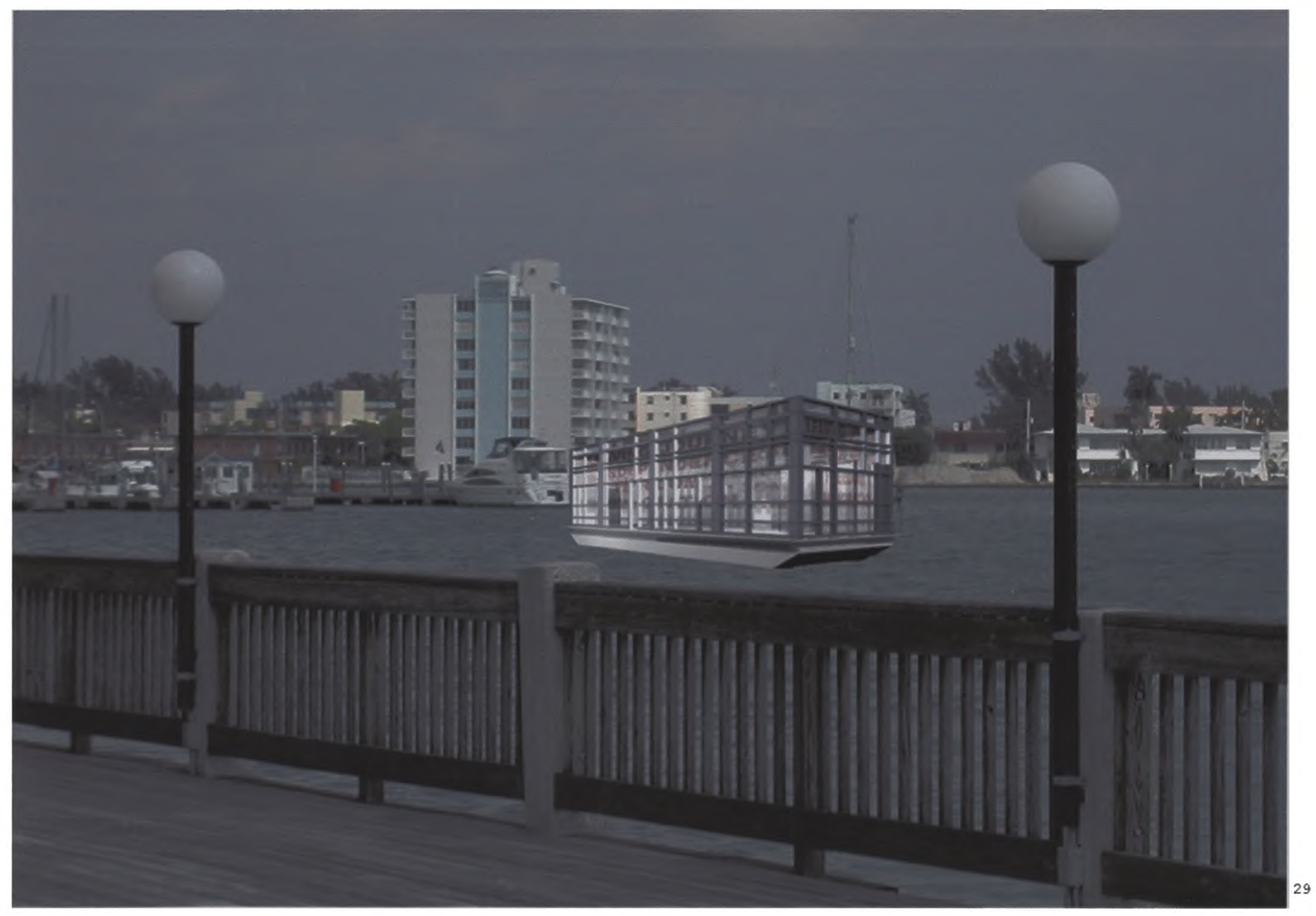




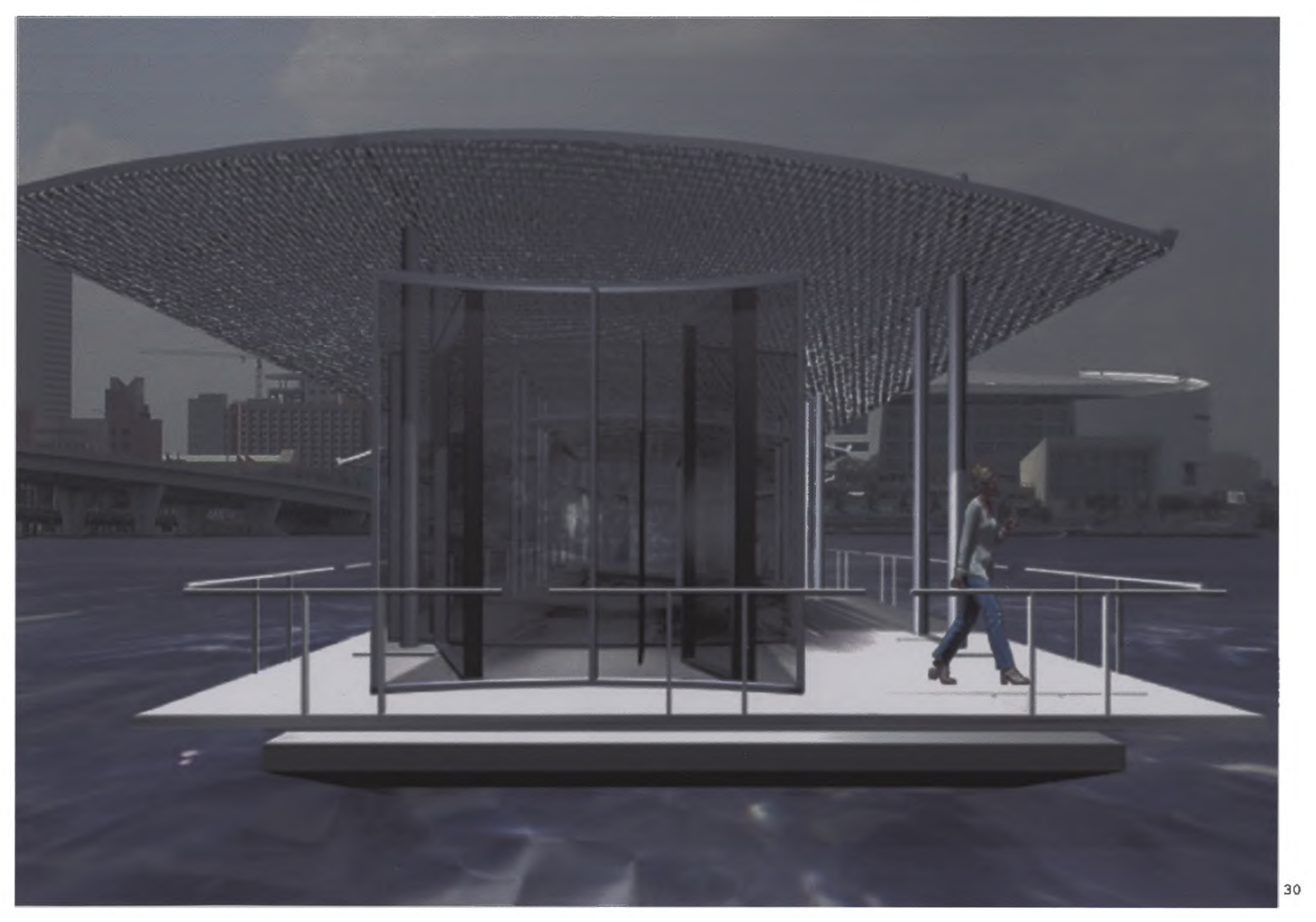




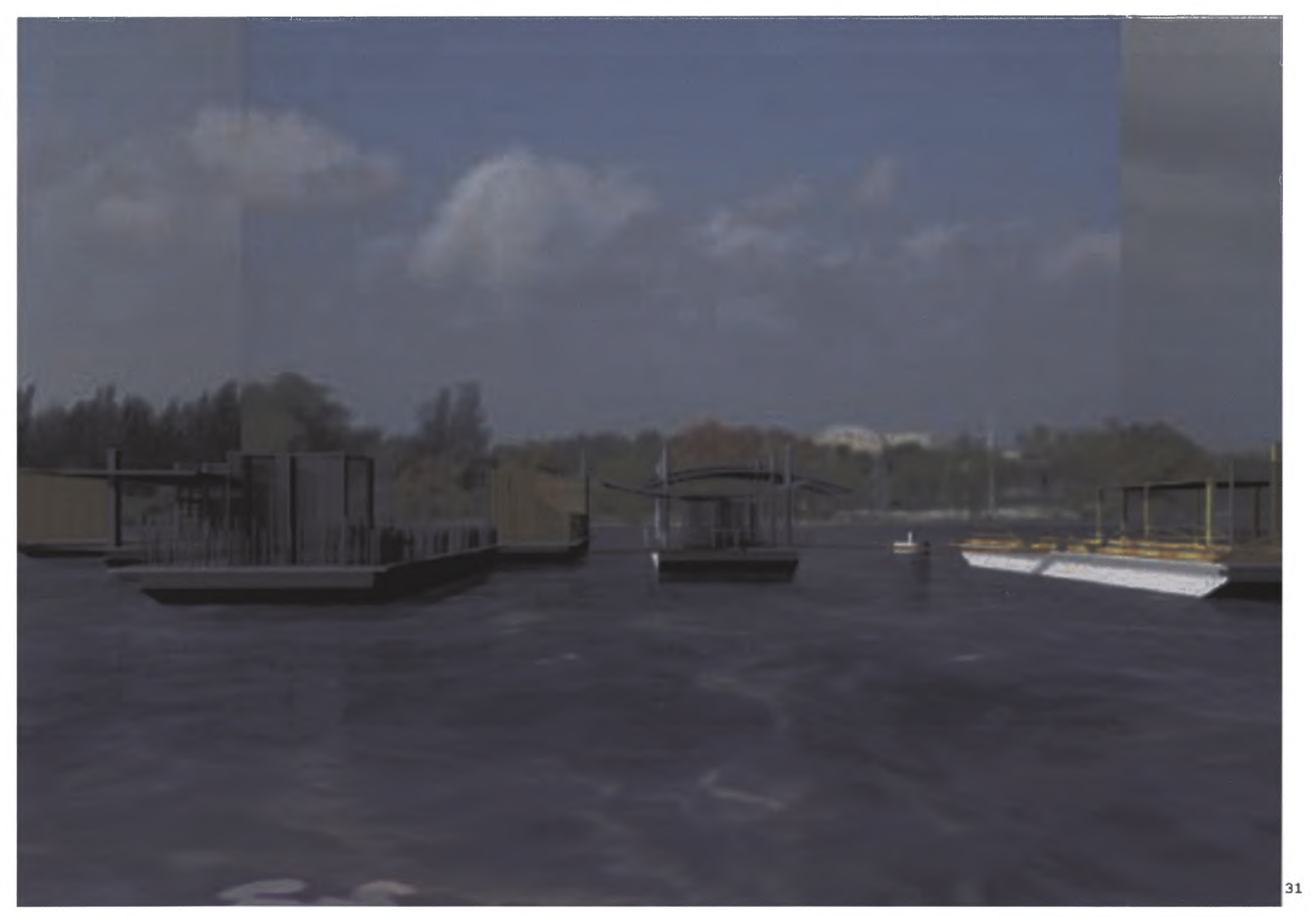




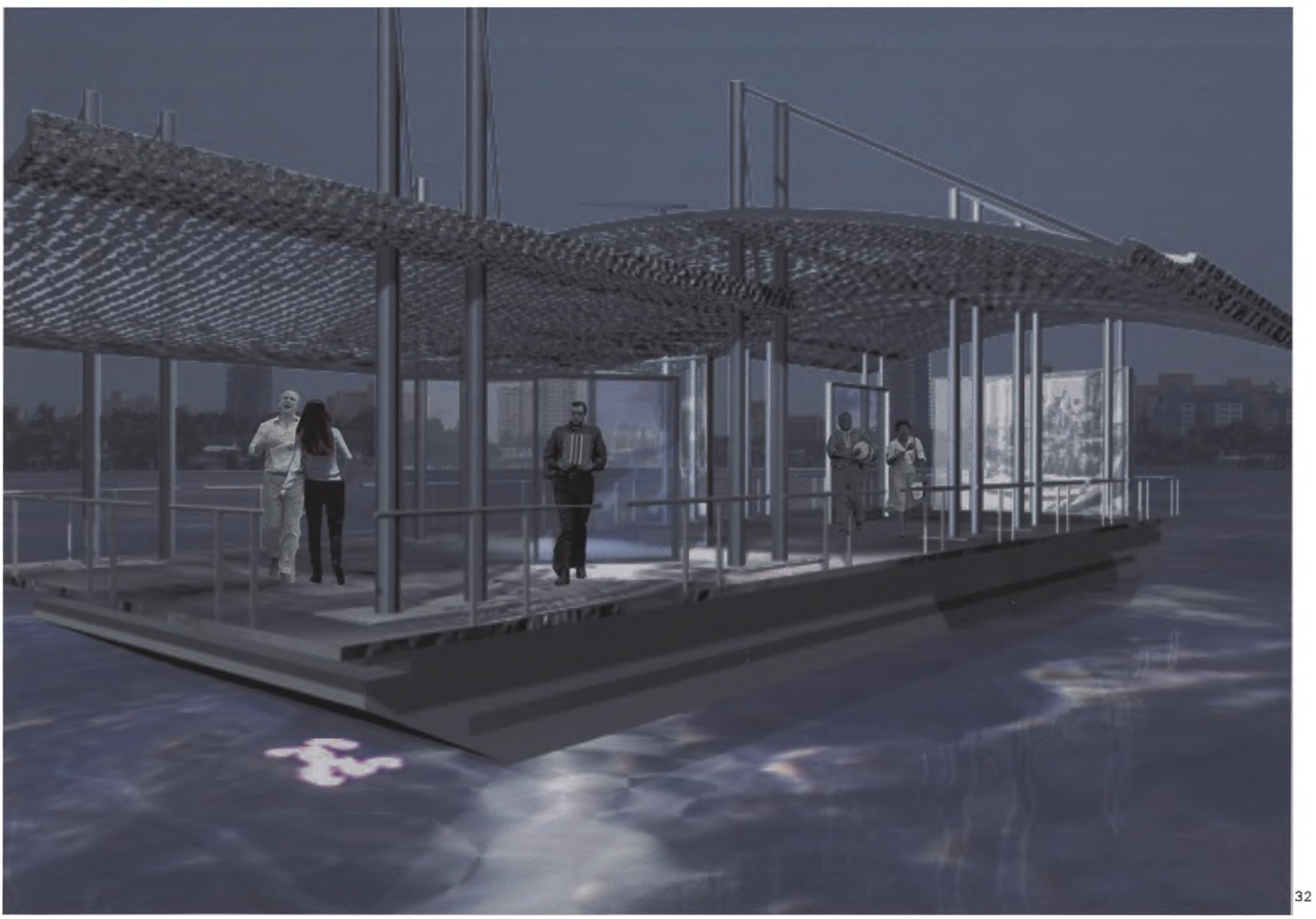




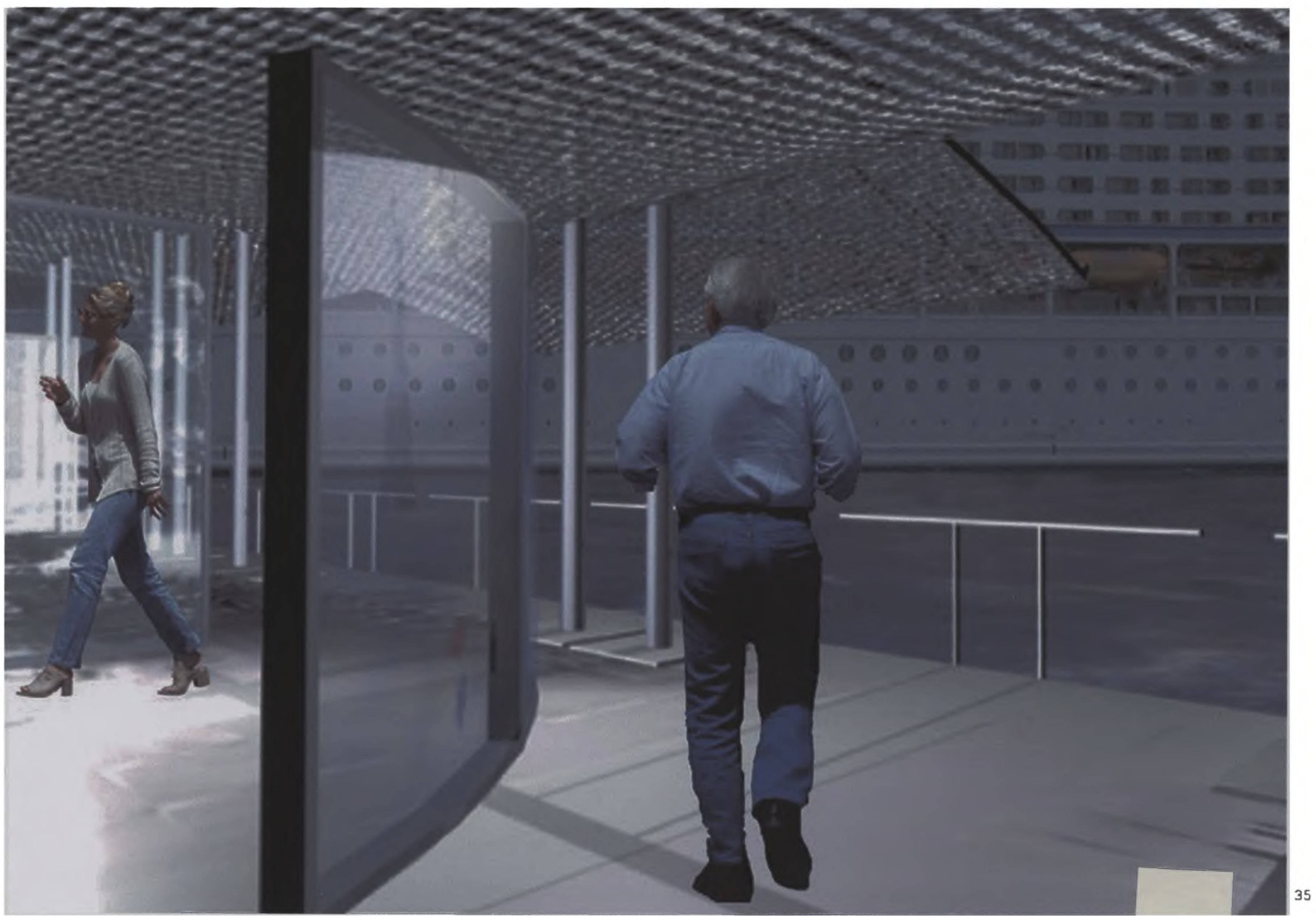




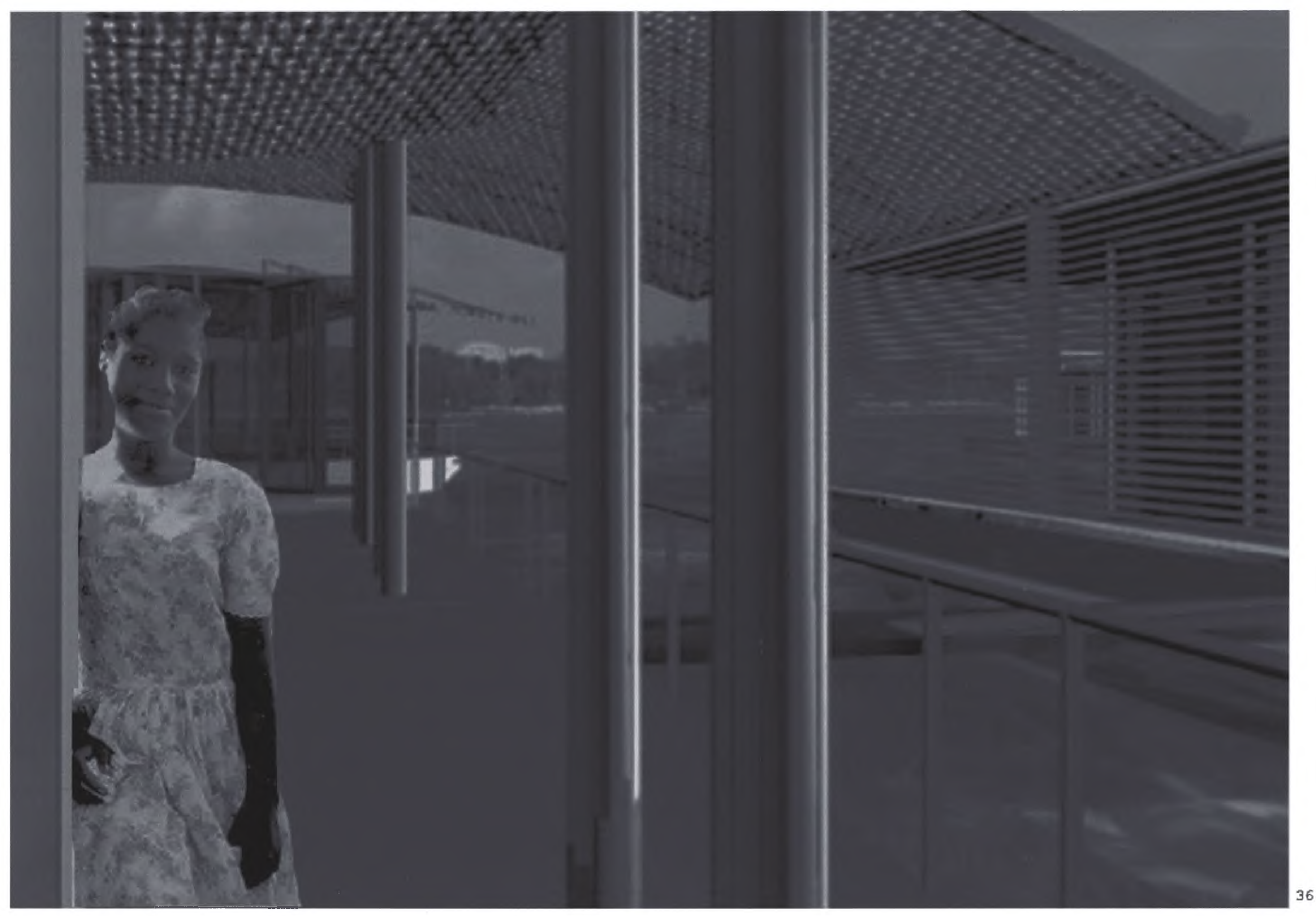




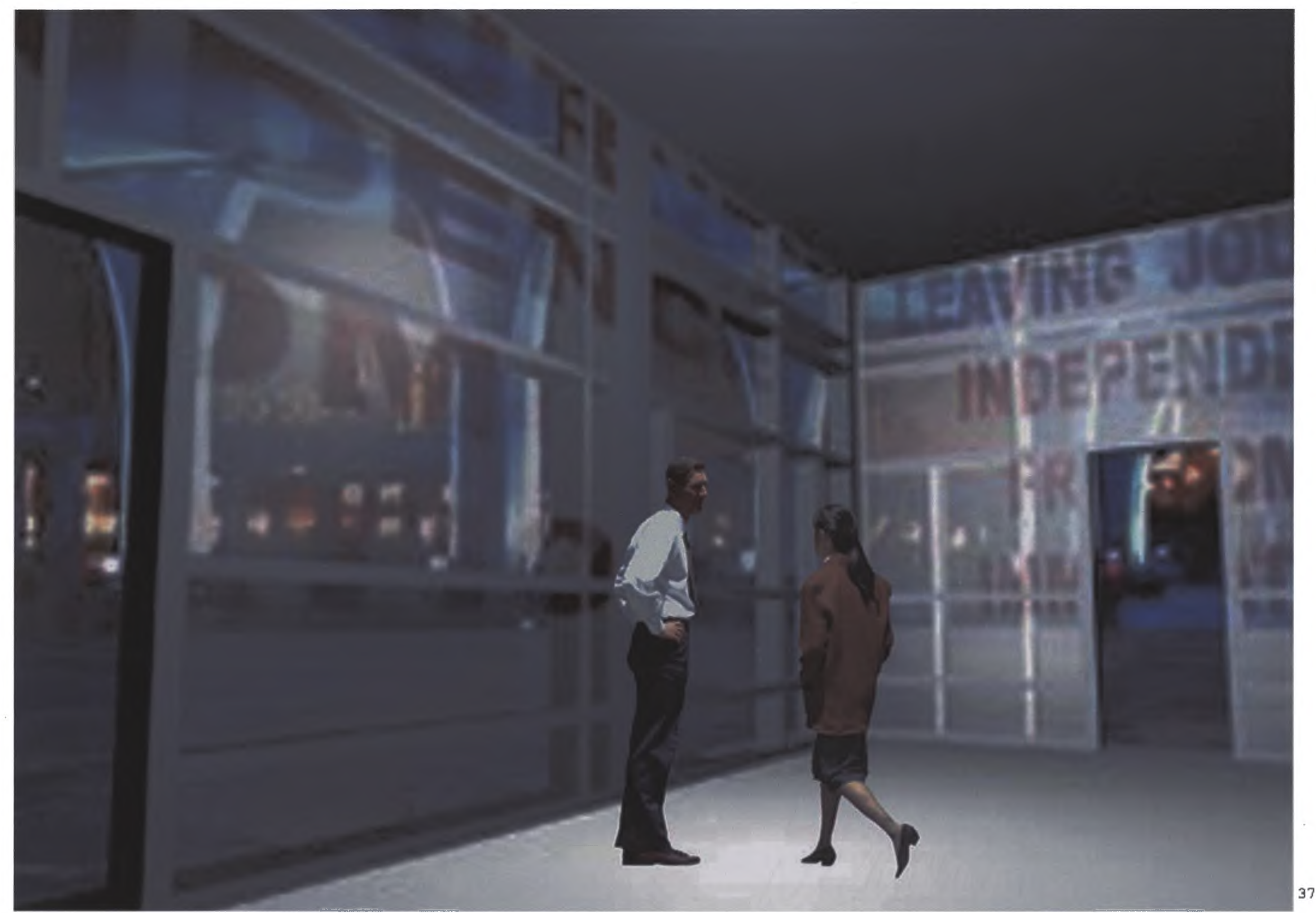




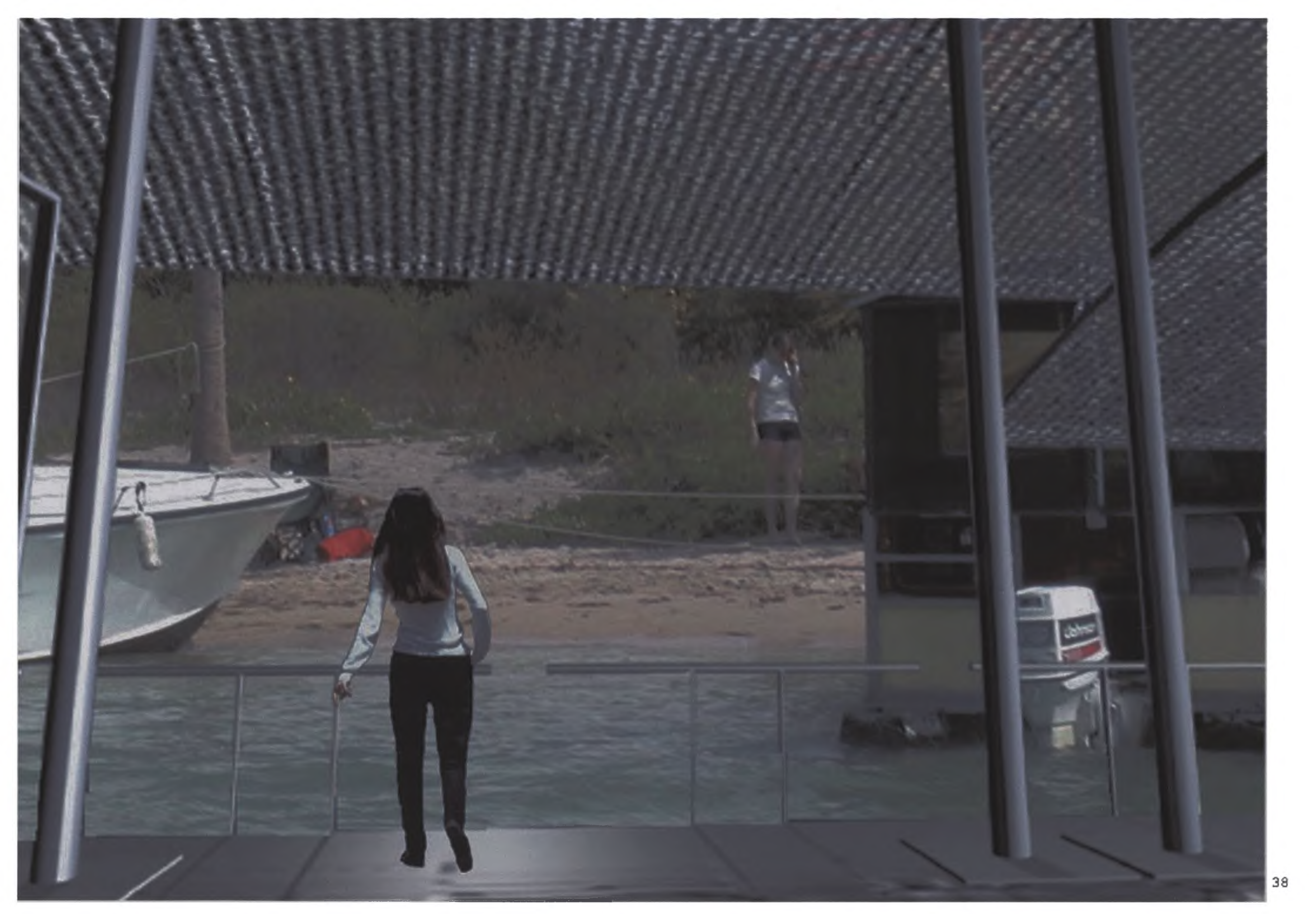


THE CITY VIEW THOUGH THE MUSEUM 


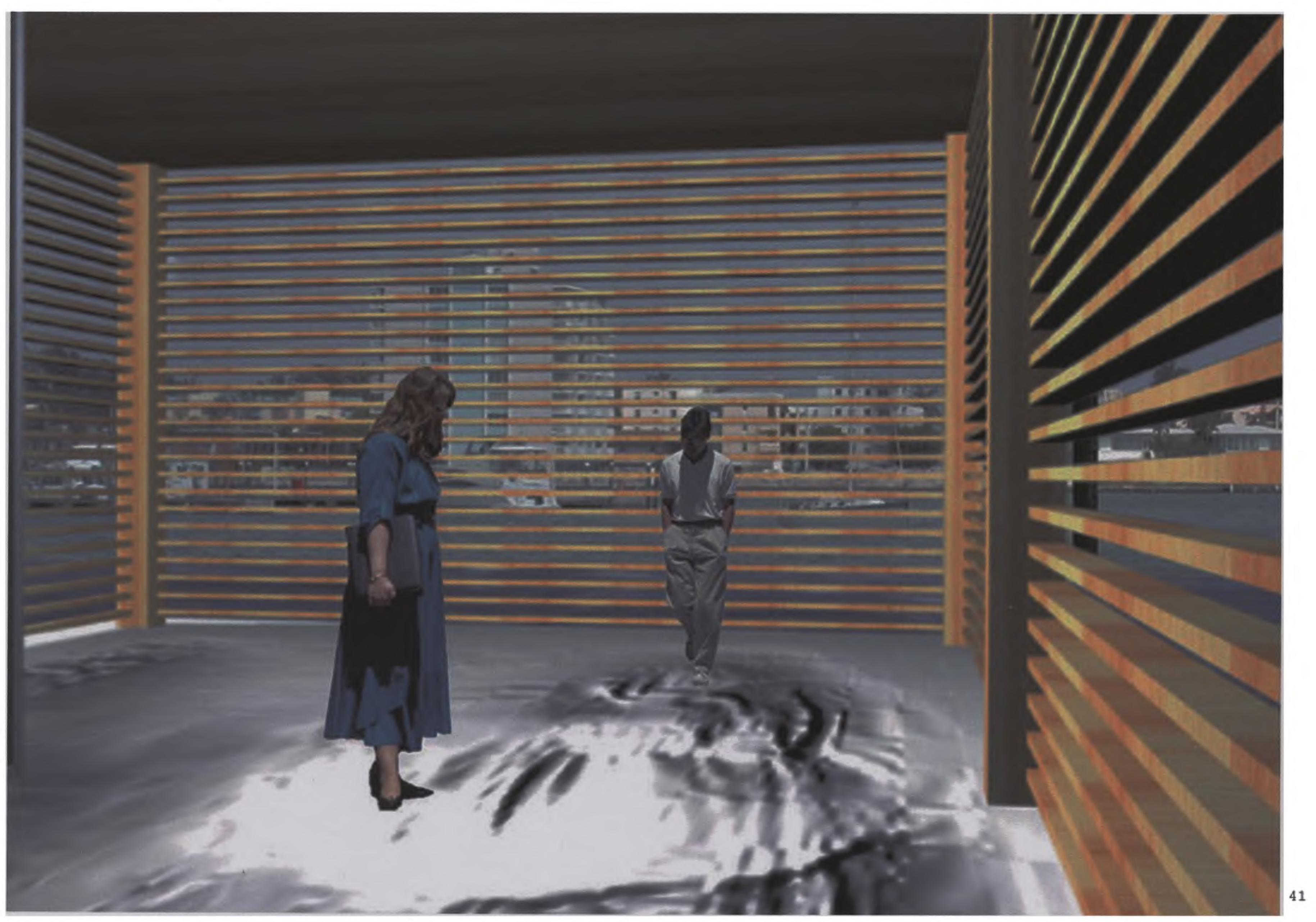




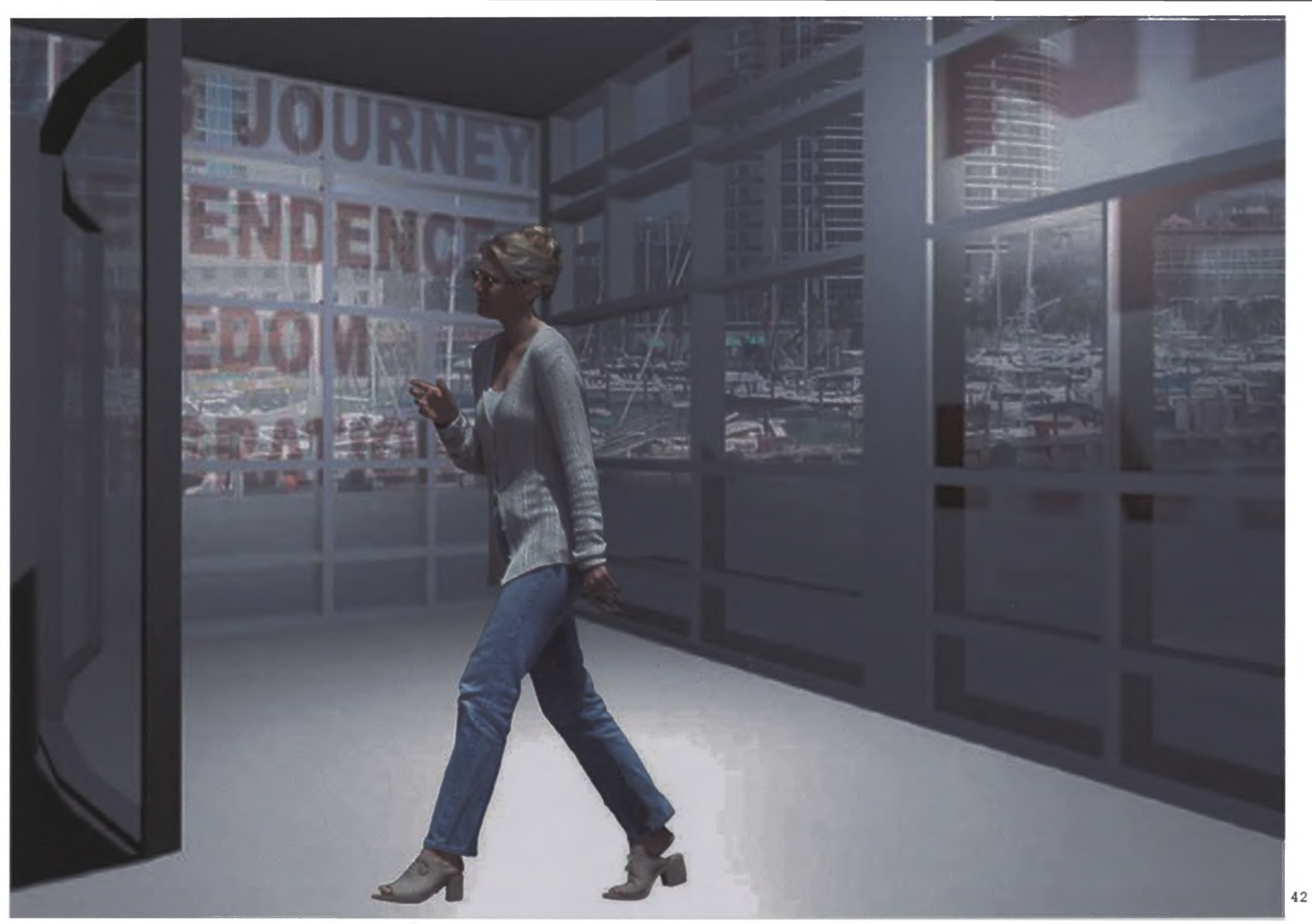




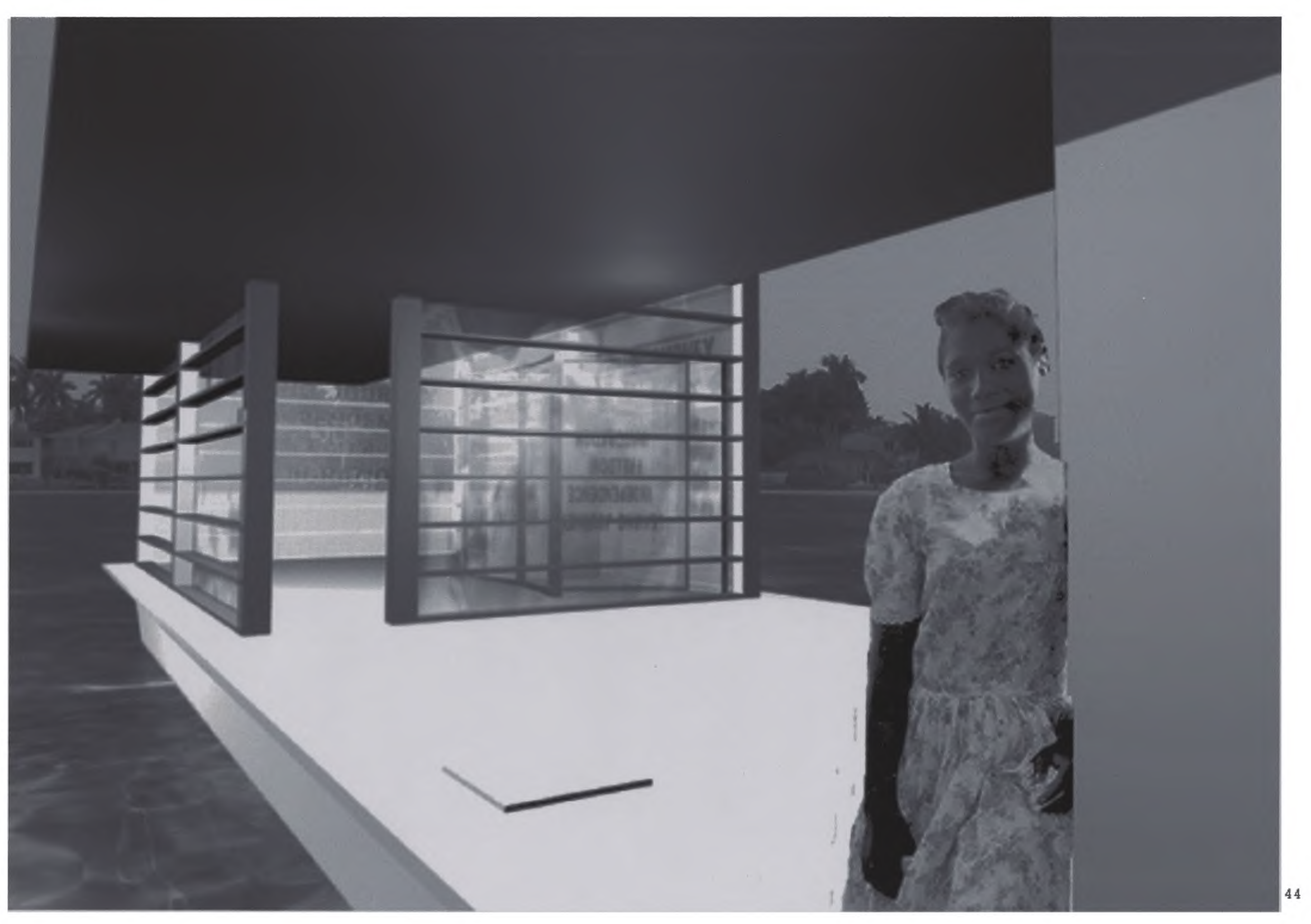




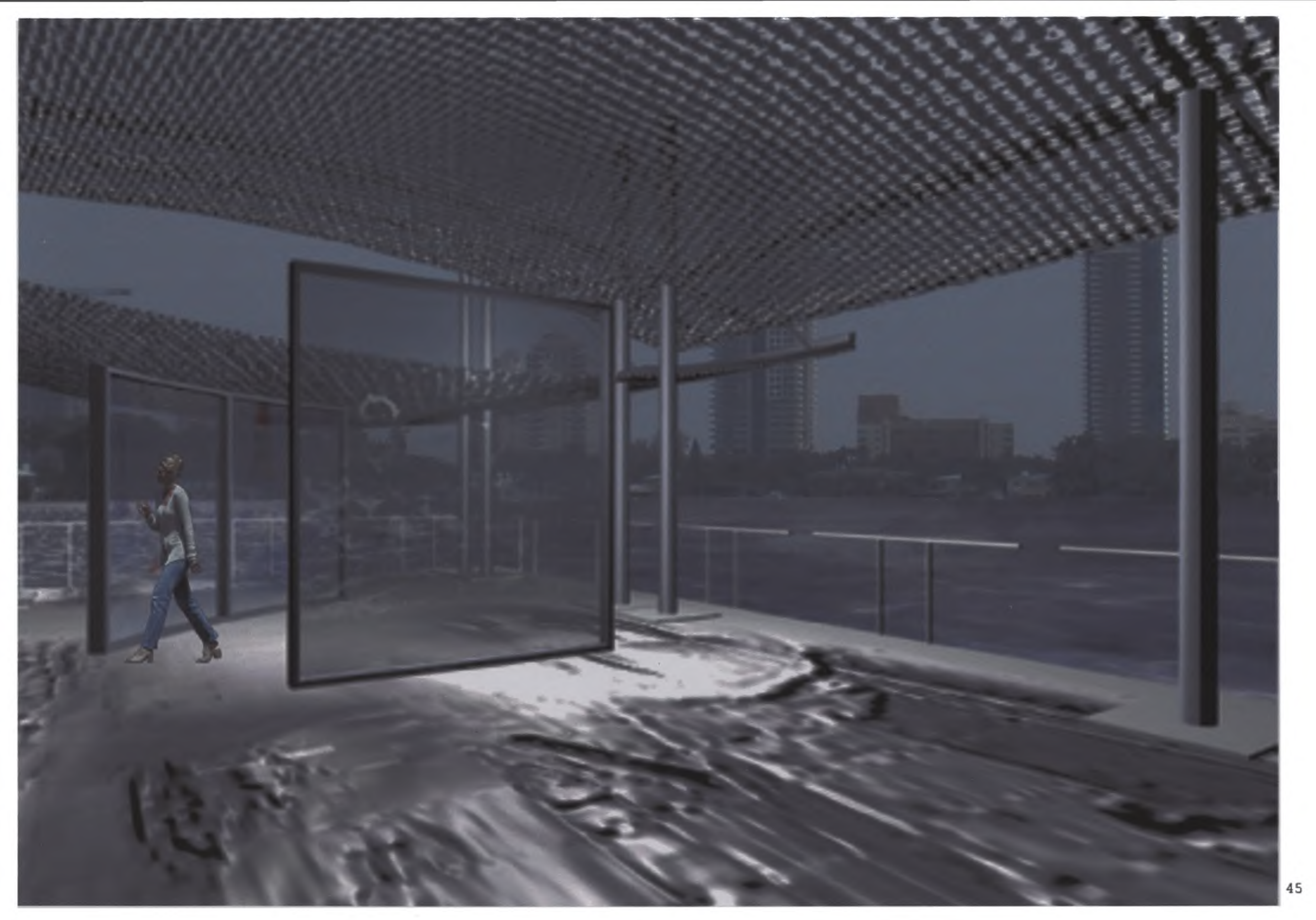




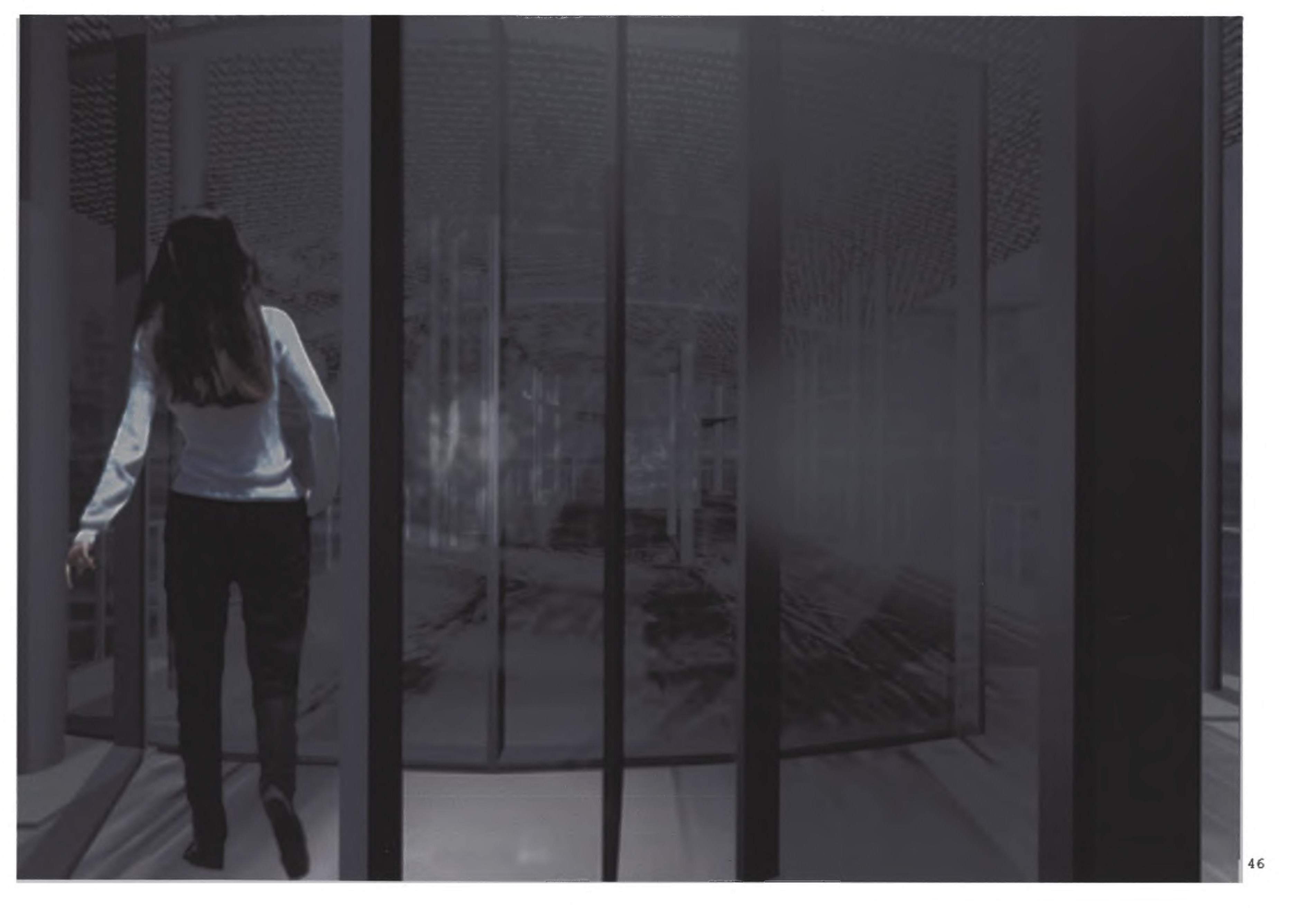




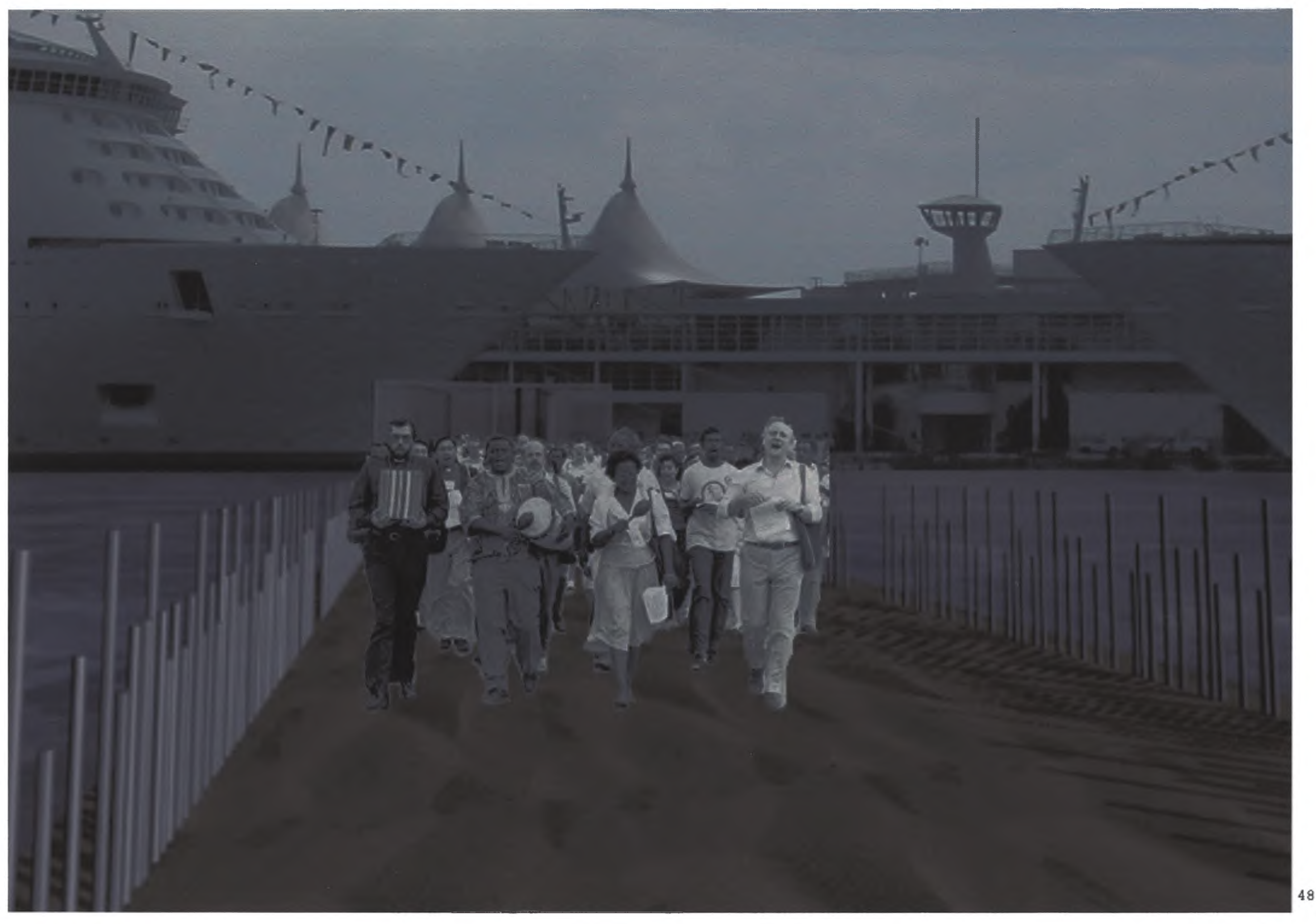




\section{List of Credits}

Figure 1- Guggenheim Museum Bilbao, Frank Gehry Architect http://www.guggenheim.org/exhibitions/past_exhibitions/gehry/

Figure 2- The Blur Building Diller and Scofidio, Architects http://www.designboom.com/eng/funclub/dillerscofidio.html

Figure 3- Teatro del Mondo, Aldo Rossi Architect ww.pritzkerprize.com/rossi/rossipg.htm

Figure 4- Teatro del Mondo, Aldo Rossi Architect http://www.archinform.net/projekte/250.htm?ID=dfc3e714fc0d267fb8ac334c 8287 ed 93

Figure 5- Floating Architecture, Woodie Roehmer

http: //www thing .net/ grist/Ind/lettrist/wr-fl04.htm

Figure 6- Dinner Key terminal, Richter Library

http://www.library.miami.edu/archives/panam/dinner.html

Figure 7- Intercostal of South Florida Bay http://www.globexplorer.com with interested site plan

Figure 8- Traditional vietnamese houseboats

http://www.nationalgeographic.com/adventure/0105/field/popup8_cove.htm

Figure 9- Dinner Key Terminal, Richter Library

http://www.library.miami.edu/archives/panam/dinner.html

Figure 10- Water Pavilion, Floriade, Haarlemmermeer

2002http://wWw.h2olland.nl/h2o/project 02.08.03.xml.html

Figure 11- Houseboats

http://www.ischo.com/china/photos_04.12.2001/img_0864.jpg

Figure 12- Teatro del Mondo, Aldo Rossi Architect

http: //www archinform. net/projekte/250.htm? ID=dfc3e $714 \mathrm{fc0d} 267 \mathrm{fb} 8 \mathrm{ac} 334 \mathrm{c}$ 8287 ed93

Figure 13- Stiltsville, Biscayne Bay

http: //www.heraldstore.com/shp_order_photo.asp?photo no $=28$

Figure 14-Floating Architecture, Woodie Roehmer

http://www.thing.net/ grist/lnd/lettrist/wr-fl04.htm

Intercostal of South Florida Bay

http://www.globexplorer.com
Figure 15- Houseboats

http://www.art. net/Studios/Visual/Hungly/NGOCAU/houseboats.htm]

Figure 16- Floating Architecture, Woodie Roehmer

http://www.thing.net/ grist/lnd/lettrist/wr-fl04.htm

Figure 17- Teatro del Mondo, Aldo Rossi architect

www.pritzkerprize.com/rossi/rossipg.htm

Figure 18- Iris Edged Yatsuhashi (eight fold japanese bridge) http://www. explorejapan.com/jgardens.htm

Figure 19- Mariel Refugee

http://cuban-exile.com/doc 026-050/doc0038.html

Figure 20- Cuban Migrants Arrive in Key West aboard the fishing vessel Big Bruce. USCG photo.

http://www.uscg.mil/reserve/magazine/mag2000/apr2000/marie.htm

Figure 21- Cuban Refugee

http://www.collegeem.qc.ca/cemdept/francais/jylaporte/amerique/critiqu es.htm

Figure 22- 1980 Cuban Exodus

http://www.uscg.mil/hq/g-cp/history/USCG_Mariel_History_1980.html

Figure 23- Docks. Background Ocean chart by International Sailing supplies (813) 639-7626 Photographic reproduction of National Ocean Survey chart \#11467

Figure 24- Background picture (Haulover Beach Park Marina) from http://www.miamidade.gov/parks/marinas.htm juxtapose $3 \mathrm{~d}$ rendering by Valeria G. Bettoli

Figure 25- Background picture (Pelican Harbor Marina) from http://www.miamidade.gov/parks/marinas.htm juxtapose 3d rendering by Valeria G. Bettoli

Otherwise indicated pictures, 3D renderings and plans were produced by Valeria G. Bettoli 
Bibliography*

Agrest, Diane. Architecture from Without. (Cambridge: The MIT Press, 1991).

Argan, Giulio Carlo. Borromini (Milan : Sansoni, 1996.)

Barrie, Thomas. Spiritual path, sacred place: myth, ritual, and meaning in architecture (Boston: Shambhala, 1996)

Blake, Peter. Master Builders- Le Corbusier, Mies van der Rohe, Frank Lloyd Wright. (New York: W.W. Norton \& Company, 1976)

Bloomer, Kent C. and Charles W. Moore. Body, Memory, and Architecture. (New Haven: Yale University Press, 1977).

Breeze, Carla. New York deco (New York: Rizzoli, 1993).

Curtis, William. La arquitectura Moderna desde 1900. (Madrid: Hermann Blume, 1986).

Curtis, William J.R. Le Corbusier Ideas and Forms. (London: Phaidon Press, 1986).

Feireiss, Kristin Ed. Badetempel. English. The water temple: Gründerzeit and Jugendstil public baths / photographs, Dieter Leistner; introduction, Annegret Burg; essays, Hans-Eberhard Hess and Dirk Meyhöfer. (London: Academy Editions; New York, NY: Distributed to the trade in the United States of America by St. Martin's Press, 1994 ).

George, Paul S. Ph.D. A journey through time : a pictorial history of South Dade (Virginia Beach, Va. : Donning Co., 1995)

Hale, Jonathan. The Old Way of Seeing. (New York: Houghton Mifflin Company, 1994).

Hale, Jonathan. Building ideas : an introduction to architectural theory (Chichester; New York : John Wiley, 2000).
Hersey, George L. Architecture and geometry in the age of the Baroque (Chicago: University of Chicago Press, 2000.)

Ito, Toyo. "On Fluid Architecture". February, 2000. Online. Available at http://www.sitesarch.org/Ito/Ito.html

Krell, David Farell. Archeticture: Ecstasies of Space, Time, and the Human Body. (New York: State University of New York Press, 1995).

Koolhaas, Rem. Delirious New York: a retroactive manifesto for Manhattan (New York: Monacelli Press, 1994).

McAnuity, Robert. "Body Troubles". In Strategies in Architectural Thinking. Cambridge: The MIT Press, 1992.

Moller, Clifford B. Architectural environment and our mental health (New York, Horizon Press 1968)

Perez-Gomez, Alberto and Stephen Pareell. Intervals in the Philosophy of Architecture. (London: McGill-Queen's University Press, 1994).

Raeburn, Michael Ed. Architecture of the Western World (New York : Rizzoli, 1980.

Rossi, Aldo. Aldo Rossi, Architetture, 1959-1987. (Milano : Electa, 1987)

Sanders, Joel. Stud. Architectures of Masculinity. (New York Princeton School of Architecture, 1996).

Smith, Peter F. Architecture and the human dimension (Westfield, N.J.: Eastview Editions, 1979).

Speidel, Manfred Ed. Team Zoo : buildings and projects 1971-1990 (New York : Rizzoli, 1991).

Weisman, Leslie Kanes. Discrimination by Design. (Chicago: University of Illinois Press, 1992). 